\title{
A Review on Building Integrated Photovoltaic Façade Customization Potentials
}

\author{
Daniel Efurosibina Attoye * (D), Kheira Anissa Tabet Aoul (D) and Ahmed Hassan \\ Department of Architectural Engineering, United Arab Emirates University, Al Ain 15551, UAE; \\ kheira.anissa@uaeu.ac.ae (K.A.T.A.); ahmed.hassan@uaeu.ac.ae (A.H.) \\ * Correspondence: 201590088@uaeu.ac.ae; Tel.: +971-52-971-6472
}

Received: 15 September 2017; Accepted: 22 November 2017; Published: 9 December 2017

\begin{abstract}
Technological advancement in Building Integrated Photovoltaics (BIPV) has converted the building façade into a renewable energy-based generator. The BIPV façade is designed to provide energy generation along with conventional design objectives such as aesthetics and environmental control. The challenge however, is that architectural design objectives sometimes conflict with energy performance, such as the provision of view and daylight versus maximum power output. In innovative cases, the characteristics of conventional BIPV façades have been modified by researchers to address such conflicts through customization as an emerging trend in BIPV façade design. Although extensive reviews exist on BIPV product types, design integration, adoption barriers and performance issues, research on BIPV customization has not been reviewed as a solution to BIPV adoption. This paper seeks to review the potential of BIPV façade customization as a means of enhancing BIPV adoption. The current paper identifies customization parameters ranging from the customization category, level, and strategies, and related architectural potential along with an assessment of their impact. The findings reflect that elemental and compositional level customization using combined customization strategies provide enhanced BIPV products. These products are well integrated for both energy generation and aesthetic applications with a power output increase of up to $80 \%$ in some cases. The paper concludes that a wide range of BIPV adoption barriers such as aesthetics, architectural integration, and performance can be overcome by appropriate BIPV customization.
\end{abstract}

Keywords: Building Integrated Photovoltaics (BIPV); façade; customization; architectural potentials; barriers

\section{Introduction}

Buildings are a main source of global energy consumption and $\mathrm{CO}_{2}$ emissions; accounting for about $40 \%$ of global energy consumption [1,2] The international contribution to sustainability has generated a large number of publications in relevant journals and conferences over the last four decades [3] and has established a dire need to reduce greenhouse gas emissions [4-6] as these gases are potential causes of threats to the ecosystem such as global warming [7-10]. From the Kyoto protocol of 1997 to the Paris Agreement of 2015, various policy directions have been motivated to mitigate international environmental pollution. Mitigation in various dimensions is a key factor to improving the environment for future generations [11,12]. At the building scale, the potential of on-site renewable energy generation to optimize energy demand and supply infrastructure has been investigated [13-15]. This provides an opportunity to address environmental pollution; which has frequently been linked with the rising level of nonrenewable energy consumption [5]. Building Integrated Photovoltaics (BIPV) provides such an opportunity through clean micro-energy generation being adoptable to various building designs. Several studies indicate that application of BIPV leads to substantial energy savings [16-18] and thus related gains in energy consumption and reduction of pollution sources. BIPV reduces the damage done to the ecosystem through conventional energy sources [19] and is 
a promising way of relieving the increasing financial and environmental costs of fossil fuel energy generation [20]. Technological advancements have evolved BIPV into a PV application with the capability of electrical delivery at a comparatively lower cost than grid electricity for certain end users in certain peak demand niche markets [21]. As a contemporary material available to architects, BIPV serves simultaneously as a part of the building envelope and an energy source. BIPV systems can be more cost effective simply because their composition and location replaces a number of conventional components and thus provide multiple gains which are reviewed in details in this paper. These include savings in materials and electricity costs, reduced use of fossil fuels, decreasing carbon and greenhouse gases emissions and improved architectural image of the building [22,23].

However, several studies highlight various barriers which are limitations to the widespread adoption of BIPV [24-34]. They range from general product issues such as performance, aesthetics and technical complexity [26] to specific regional issues such as the need for extensive education on professional and public levels $[24,25,27]$. Greater attention to research and development in customization and BIPV product designs with good architectural aesthetics and integrality have been suggested by reviewers as potential solutions to these $[25,26,28,32]$. However, our survey of recent BIPV reviews over the last 5 years (Table 1) shows that there is only limited information on customization as potential driver for BIPV adoption. Only partial attention has been made of custom BIPV; relating to mention of strategies [35,36] and cost limitations [37]. In two other cases [38,39] a descriptive inventory of several market-ready custom BIPV product applications connecting cell technology and architectural integration is given [38]. Also, details on the possibilities, market options, and aesthetic levels of customizability were presented [39].

Table 1. Summary of customization content in recent Building Integrated Photovoltaics (BIPV) reviews.

\begin{tabular}{|c|c|c|}
\hline Reference & Title/Focus & Customization-Related Content \\
\hline [40] & Recent advancement in BIPV product technologies: a review & - \\
\hline [41] & $\begin{array}{l}\text { Embedding passive intelligence into building envelopes: a } \\
\text { review }\end{array}$ & Reference to a system-based process design \\
\hline [35] & $\begin{array}{l}\text { A critical review on building integrated photovoltaic } \\
\text { products and their applications }\end{array}$ & Brief mention \\
\hline [22] & $\begin{array}{l}\text { Double skin façades (DSF) and BIPV: a review of } \\
\text { configurations and heat transfer characteristics }\end{array}$ & Inference to different design modes \\
\hline [42] & $\begin{array}{l}\text { A comprehensive review on design of building integrated } \\
\text { photovoltaic system }\end{array}$ & $\begin{array}{l}\text { Reference made to an energy-conscious process } \\
\text { design }\end{array}$ \\
\hline [39] & $\begin{array}{l}\text { Overview and analysis of current BIPV products: new } \\
\text { criteria for supporting the technological transfer in the } \\
\text { building sector }\end{array}$ & $\begin{array}{l}\text { Possibilities, market options, aesthetic levels; an } \\
\text { architectural layering process design approach }\end{array}$ \\
\hline [43] & PV glazing technologies & - \\
\hline [36] & $\begin{array}{l}\text { Building Integrated Photovoltaics: a Concise. Description of } \\
\text { the Current State of the Art and Possible Research Pathways }\end{array}$ & Brief mention \\
\hline [37] & $\begin{array}{l}\text { Building Integrated Photovoltaics (BIPV): review, Potentials, } \\
\text { Barriers and Myths }\end{array}$ & $\begin{array}{l}\text { Brief mention of the need, possibilities and } \\
\text { challenges }\end{array}$ \\
\hline [38] & $\begin{array}{l}\text { 'State-of-the-art' of building integrated photovoltaic } \\
\text { products }\end{array}$ & $\begin{array}{l}\text { Details on available custom products in the } \\
\text { market }\end{array}$ \\
\hline$[44]$ & $\begin{array}{l}\text { Building integrated photovoltaic products: a state-of-the-art } \\
\text { review and future research opportunities }\end{array}$ & $\begin{array}{l}\text { Possibilities and available custom products in the } \\
\text { market }\end{array}$ \\
\hline [45] & $\begin{array}{l}\text { The path to the building integrated photovoltaics of } \\
\text { tomorrow }\end{array}$ & $\begin{array}{l}\text { Brief mention of possible future in product } \\
\text { variety }\end{array}$ \\
\hline [46] & $\begin{array}{l}\text { Whole systems appraisal of a UK Building Integrated } \\
\text { Photovoltaic (BIPV) system: energy, environmental, and } \\
\text { economic evaluations }\end{array}$ & - \\
\hline [47] & $\begin{array}{l}\text { Photovoltaics and zero energy buildings: a new opportunity } \\
\text { and challenge for design }\end{array}$ & - \\
\hline [48] & Architectural Quality and Photovoltaic Products & Mention of examples, function and challenges \\
\hline
\end{tabular}


Furthermore, no information or review of experimental investigations on customization is presented to theorize its description or justify its potentiality. This review paper aims to fill this gap as identified in the literature by investigating the characteristics, strategies and potentials of BIPV customization. In addition, the study seeks to showcase the opportunities provided by customization to address the barriers of conventional BIPV.

\subsection{BIPV Customisation: Working Definition}

Customization is, "the action of modifying something to suit a particular individual or task" [49]. It can also be described as the configuration of products and services to meet customers' individual needs [50]. These definitions suggest that customization is directly associated with the identification of a function, need or objective. As it relates to BIPV, several customization objectives have been investigated, such as aesthetics [51,52], architectural integration [53,54], thermal management [55-57], and shading $[15,41,53]$. These objectives consequently determine the added function of the designed custom BIPV façade along with energy production from the solar cells. Ref. $[39,58]$ suggest that BIPV designs can follow a systematic design process. This infers that various levels/stages of customization are identifiable; [39] suggests a cell, module, and façade level activity while [58] presents an elemental, compositional, and integrational level of interest. In both representative cases, the idea is to first customize the cell, then the module, and finally the façade.

\subsection{Research Design}

The present review is divided into three main sections; first an overview on BIPV façades, then an appraisal of standard BIPV barriers, and finally a review of BIPV façade customization studies. Data collection and analysis steps of relevant studies for all sections of this paper were limited to English-language studies found in the ScienceDirect and Google Scholar database. In Section 1, an assessment of the mention given to BIPV customization in previous state-of-the art reviews was presented to validate the need for this investigation. For Section 2, we identified eleven (11) studies within the past five years which focused primarily on a review of barriers inherent to BIPV in general, BIPV products or to BIPV adoption. The selection was limited to the last five years, as BIPV is an evolving technology and this review seeks to identify current mitigating issues. These studies collectively represent the views of several researchers drawn from surveys involving close to 1000 respondents, based on experiences and findings from professionals and researchers worldwide. In Section 3, keywords such as "BIPV customization", "custom BIPV", "customized BIPV" were used in our search, but at the time of writing this review, no studies with these exact words were found. We expanded our search for related titles on BIPV façade customization and identified 25 representative studies with related abstracts and thus focused our investigation on these. Figure 1 shows a color-coded mind map for this investigation; it reflects the research direction and connections, as well as a basis for deductive reasoning which informs the resulting conclusions made in this review. The blue-coded section groups together the research on BIPV types and potential benefits which are discussed in detail later in Section 2 (Overview on BIPV façades). The red coded section combines the barriers that affect BIPV adoption into the built environment later discussed separately in Section 3 (BIPV barriers). The green coded sections put together the specifics of customization as an approach to enhance BIPV adoption into built environment later discussed in Sections 4.1 and 4.2 (BIPV customization investigations). The detailed discussions on the specific findings of the mind map are discussed in the following Sections 2-4. 


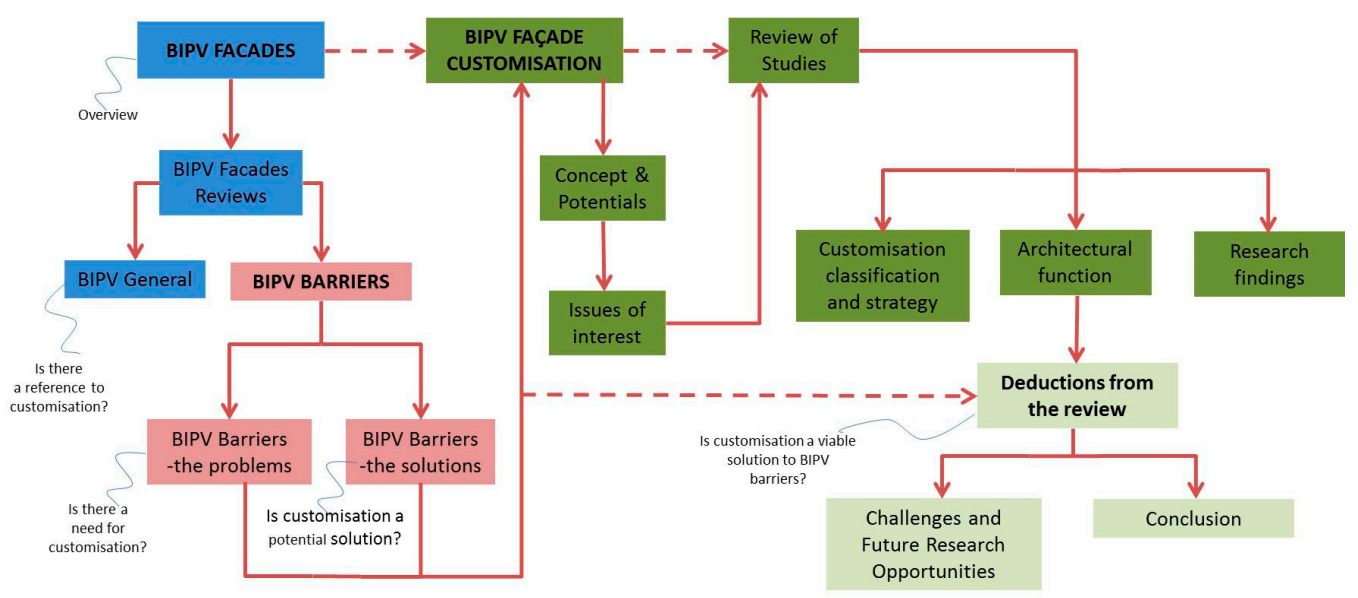

Figure 1. BIPV façade customization review mind map. Source: authors.

\section{Overview on BIPV Façade Applications}

The building façade is conventionally made up of walls, glazing, cladding and fenestrations; and other structures like shading devices, parapets and balconies. Each of these building components provide opportunities for integrating PVs to the building and by extension, for façade customization [36,37,59-62]. The main BIPV façade applications extracted from literature $[39,43,59,61,63]$ include curtain walls, glazing, external/shading devices, and innovative applications. Table 2 presents an overview of these applications using representative built examples to describe the advantages and disadvantages of each of these types.

Table 2. Design impact of BIPV façade types. Source: authors.

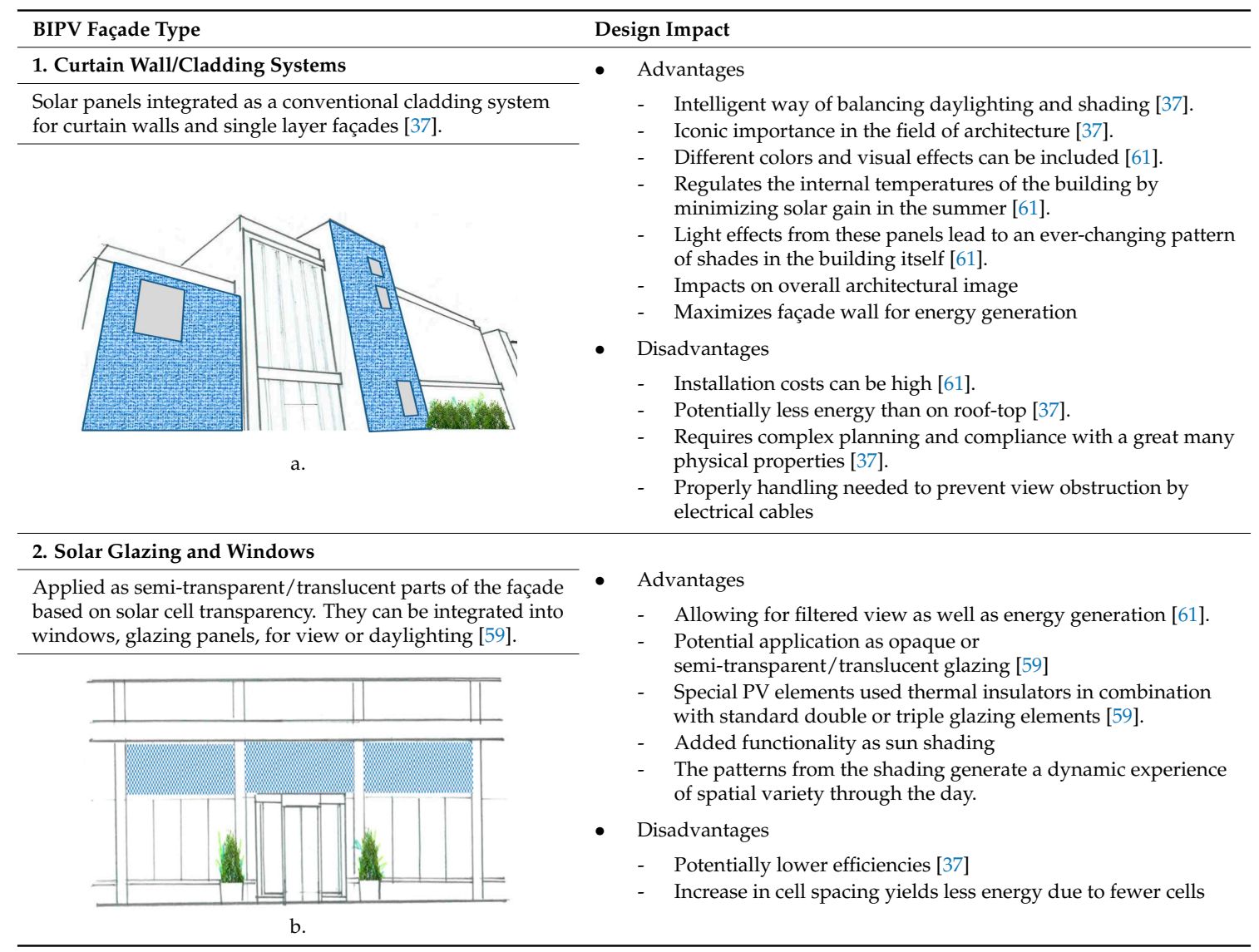


Table 2. Cont.

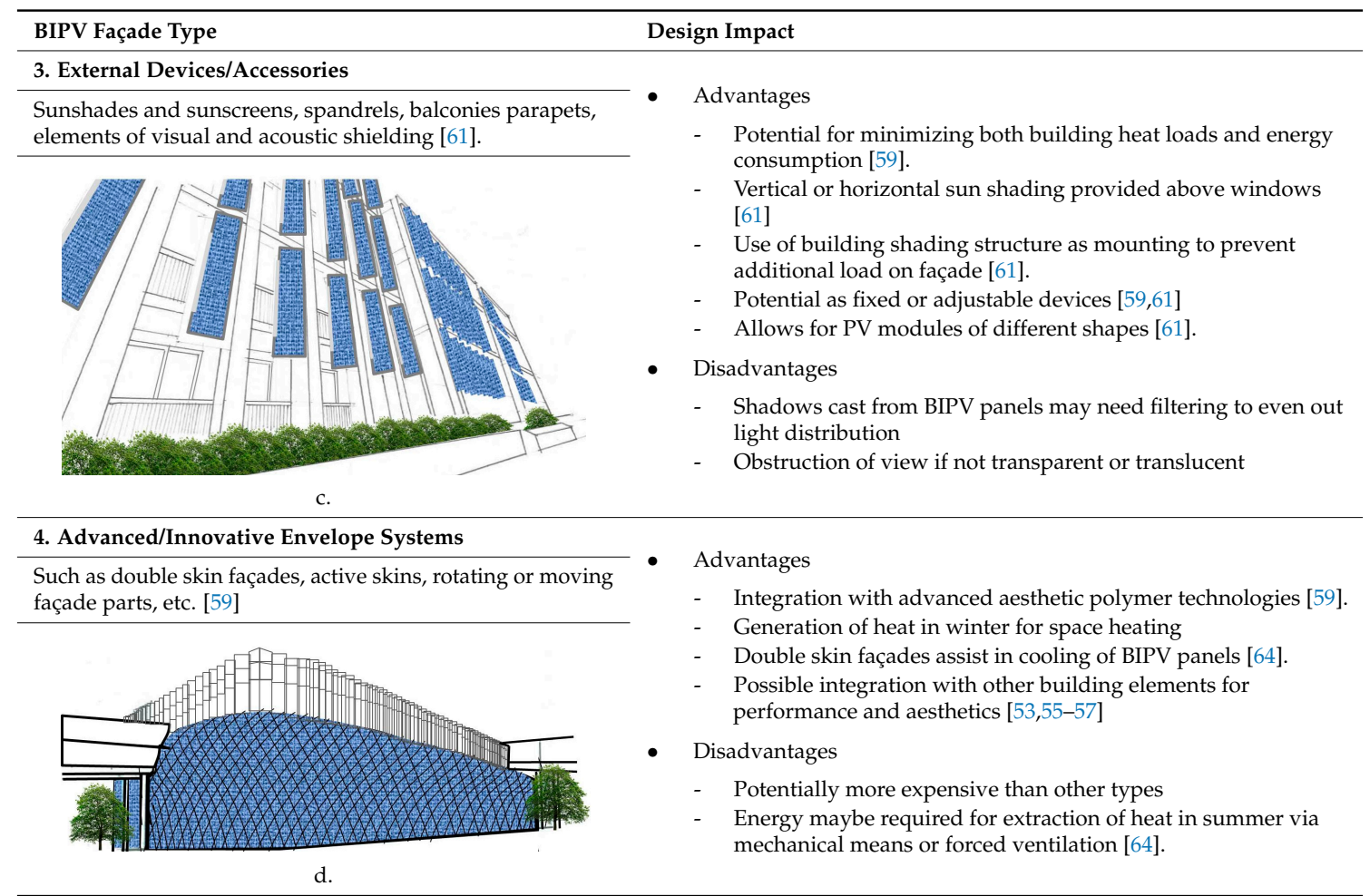

a. Curtain Wall of Hanergy Office, Guangdong, China; showing BIPV cladding; b. KTH Executive School AB, Sweden; showing glazing with wide spaced solar cells for daylighting and view; c. Shading devices on Kingsgate House London, UK; showing vertical polycrystalline panels; d. Innovative façade of Hanergy Headquarters, Beijing, China; showing innovative "dragon scale" arrangement of BIPV modules

\subsection{Strategic Benefits of $B I P V$}

BIPV is a multifunctional technology and they are therefore usually designed to serve more than one function $[36,60,65]$. Along with the fundamental function of producing of electricity, the multi-functionality of BIPV thus implies that it can fulfill several other tasks as a façade element such as solar protection and glare protection. Three identified classes of such added function or benefits from literature relate to the building envelope design, economic advantages and environmental impact.

- Design Benefits: relating to architectural integration and function of BIPV as a building component

- Economic Benefits: relating to financial advantages accrued as a result of BIPV application

- Environmental Benefits: relating to micro or macro environment improvements due to BIPV application

The list below contains a categorization of the multiple functions that BIPV modules can perform based on its unique characteristics.

1. Design-related benefits

a. View and daylighting - semi-transparent options allow for light transmission and contact with exterior $[61,66,67]$.

b. Aesthetic quality-integration in buildings as a design element $[36,61]$

c. Sun protection/shadowing/shading modulation—used as fixed or tracking shading devices $[36,37,60,61,67]$,

d. Replacement of conventional materials such as brickwork [37].

e. Public demonstration of owner's green ecological and future-oriented image [61]. 
f. Safety-applied as safety glass [61].

g. Noise protection-reaching up to $25 \mathrm{~dB}$ sound dumping [36,37,61,67].

h. Heat protection/Thermal insulation (heating as well as cooling)-improving the efficiency of cells by cooling through rear ventilation $[36,37,61]$

i. Visual cover/refraction—one-way mirroring visual cover $[60,61]$.

2. Economic Benefits

a. Removal of the need for the transmittance of electricity over long distances from power generation stations $[68,69]$.

b. Reduction in capital expenditure for infrastructure and maintenance $[68,69]$.

c. Reduction in land use for the generation of electricity $[28,70]$.

d. Material and labour savings as well as electrical cost reductions [36].

e. Reduction in additional assembly and mounting costs, leading to on-site electricity and lowering of total building material costs and significant savings [45]. In addition, ongoing costs of a building are reduced via operational cost savings and reduced embodied energy [71].

f. Combined with grid connection, FITs; cost savings equivalent to the rate the electricity is close to zero $[28,46,72]$

3. Environmental Benefits

a. Reduction of carbon emissions [28]

b. The pollution-free benefit of solar energy [45].

c. Reduces the Social Cost of Carbon (SCC) relating to the health of the public and the environment [28].

\section{BIPV Façade Applications: Barriers and Strategies}

Notwithstanding the stated multi-functionality of BIPV already expressed in several studies, its adoption is globally challenged by certain barriers. It has been argued that sustainability goals of the future can only be achieved if we look beyond new technologies themselves, and account for the complex human factors influencing their adoption and use [73]. Several researchers have investigated these barriers and their studies show that there are various perspectives and issues of concern. These include challenges in the various stages of application [30] such as the design stage and installation stage, and in some regional cases, expertise limitation, lack of promotion, and financial issues [27]. There are also key barriers that are general to BIPV adoption, and in some cases, affect the building integration of other renewable energy technologies. Some of these general issues from a more holistic point of view are sociotechnical, management, economic, and policy-related [29] as well as knowledge and information-related [26]. Others include insufficient presentation of BIPV product and project databases, lack of adequate business models, and insufficient dissemination of BIPV information [24].

In almost all of these studies, strategies for overcoming these barriers have been proposed. These strategies are drivers in various forms with the potential to advance or facilitate the BIPV implementation in the built environment. In some cases, they are proposed solutions to counter one or more barriers when fully applied. Table 3 gives a detailed overview of the findings of these related studies showing a categorization of the barriers and drivers identified to BIPV application; to clearly identify the issues of concern and potential solutions. 
Table 3. A detailed overview of identified BIPV barriers and drivers. Source: By Authors.

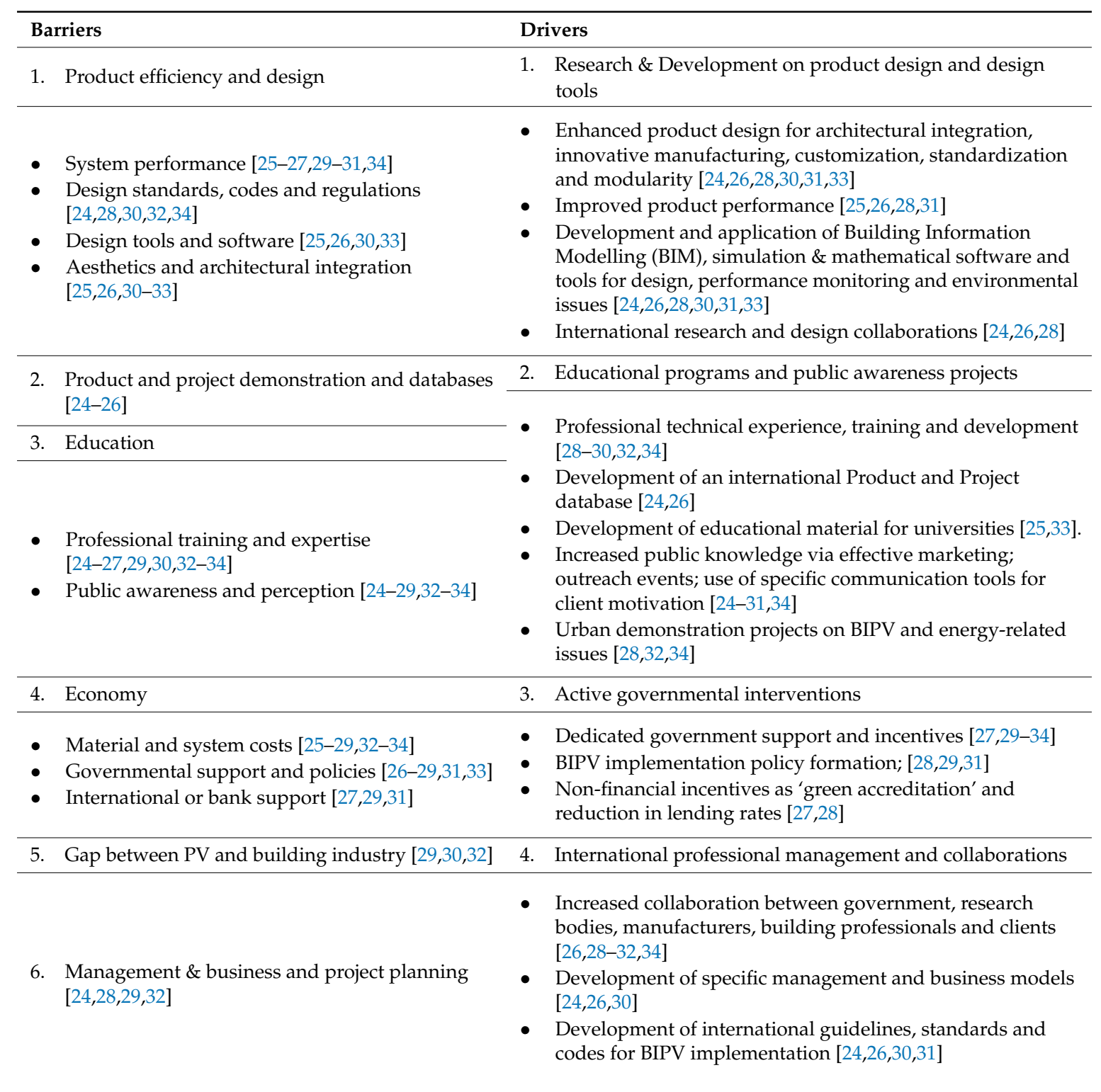

The collective information from these 11 studies represents the opinions of close to 1000 international respondents. The summary of these findings was distilled and diagrammatically presented in a force field analysis (Figure 2) for further scrutiny. A force field analysis is a management analytical tool used to conceptualize the forces interacting to promote and oppose change in a given situation [34]. We have applied it to give a visual representation of the barriers, stated as restraining factors and drivers as facilitating factors. Kurt Lewin is often acknowledged as the first to propose this technique in 1951 [74]. The weight of the arrows in this adaptation is shown in percentages, and obtained from the frequency of mention in studies of a barrier or solution. 


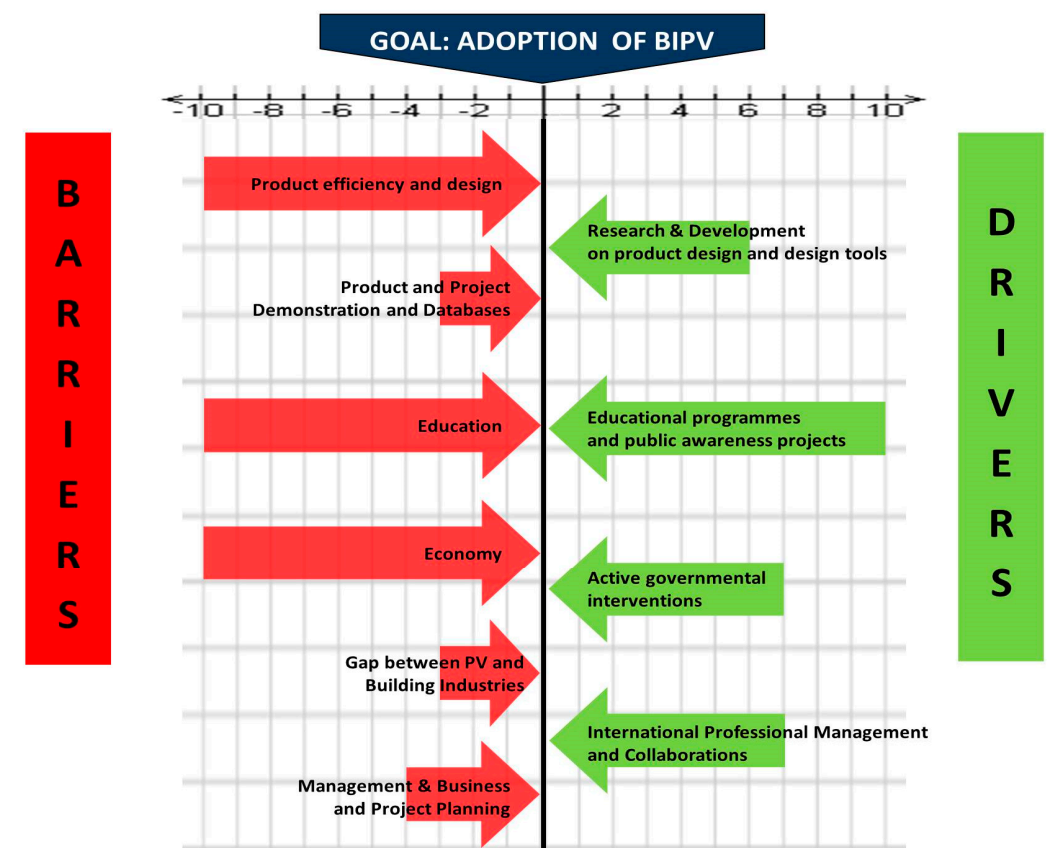

Figure 2. Simplified force field analysis of barriers and drivers of BIPV adoption. Source: By Authors.

\subsection{Force Field Analysis: Comparison of Barriers and Strategies}

Statistically speaking, six classes of barriers relating to the product, education, economy, and industry were identified in the referred literature with further sub-division of three of these classes. As an example, the product efficiency and design class encompasses related barriers such as system performance, design standards, codes and regulations. It also includes design tools and software, aesthetics and architectural integration issues. As observed from our investigation, the need to address public awareness and perception [24-29,32-34] and the insufficient professional training and expertise [24-27,29,30,32-34] are the most frequently identified barriers to BIPV adoption. This suggests an international agreement that the need for proper education regarding the potentials of BIPV is lacking in both public and professional domains. Comparatively, insufficient product and project demonstration and database, as well as insufficient international or bank support are ranked as the least identified barriers. It may be assumed therefore that client motivation via these latter support schemes may not be directly related to the reluctance to BIPV adoption. Another deduction from this survey is that comparatively, there are potentially more product efficiency and design related barriers, although education issues are deemed more crucial. It may be thus deduced that increase in education, training and expertise can be a tool to address issues with performance.

The analysis shows the combined weight of barriers is $400 \%$ (normalized to 40 ) and the combined weight of the drivers is $300 \%$ (normalized to 30 ). By increasing attention to the drivers, via increased research and development, raising each to a $100 \%$, the combined weight of the drivers will rise to $400 \%$ (normalized to 40)—assuming the barriers stay constant. In this scenario, the drivers will effectively cancel out the barriers.

With particular mention to the strategies proposed, our goal was to identify if there was sufficient information to suggest BIPV customization was a potential driver for BIPV adoption. To this end, the need for education related to design integration such as BIPV variety relating to technological choice, aesthetics, color, shape and size has been identified [25]. Improvements in product design with appeal to architects was mentioned as a potential solution; relating specifically to aesthetics $[25,26,32,33]$, directly to customization and variety $[25,26]$, and architectural integration $[25,26,28]$ and innovation [30]. Thus, customization driven by variety, aesthetics and architectural integration has been identified as a potential driver of BIPV adoption. This justifies the 
need to further investigate BIPV customization studies and the validation of their potential to address these barriers as mentioned.

\section{BIPV Façade Customization: Critical Review of Investigations}

As architects are saddled with the responsibility of building design; it is pertinent to understand fully the opportunities provided by BIPV in order to communicate them effectively to clients [75]. It has been put forward that the success of the BIPV market will in part be determined by the availability of good customizability and convincing aesthetics [39]. It terms of the need, one aspect mentioned by [76] suggests that standardized products are often not applicable when retrofitting demands flexible dimensions, and custom products have better thermal performance than conventional products [77]. Another research posits that aesthetics, dimensional requirements focused on customization capacity and functionality ought to drive the requirements for the BIPV façade [78]. Thus, this calls for innovative approaches with custom-made products as some have huge potential for energy conservation and thermal comfort [79]. Most manufacturers provide custom-made BIPV services, such as the possibility to produce modules of various power output, form, glass serigraphy/printing and colors, as well as to change the cell arrangement and the glass surface (clear glass, prism, enameled) with different properties (i.e., glare reduction) and finishing [39]. This section however, focuses on BIPV façade customization from the perspective of research investigations to identify the potentials of custom BIPV already mentioned in this review. This perspective was chosen to detail the unbiased results of research experimentation without the inhibition of market performance or worthiness.

\subsection{Methodological Approach}

This section focuses on the details of the investigative analysis of the 25 selected papers on BIPV customization. As earlier stated, the result of the review was used to check the applicability of BIPV façade customization to address the barriers of standard BIPV. Four (4) aspects of review were selected which are Innovation \& custom category, Customisation strategy, Architectural function and Research results. These describe various aspects of BIPV façade customization and form the framework for this evaluation. Figure 3 shows these related aspects as a research guide; with further explanation briefly presented following the figure to explain the definitions and state the importance of each aspect of the review.

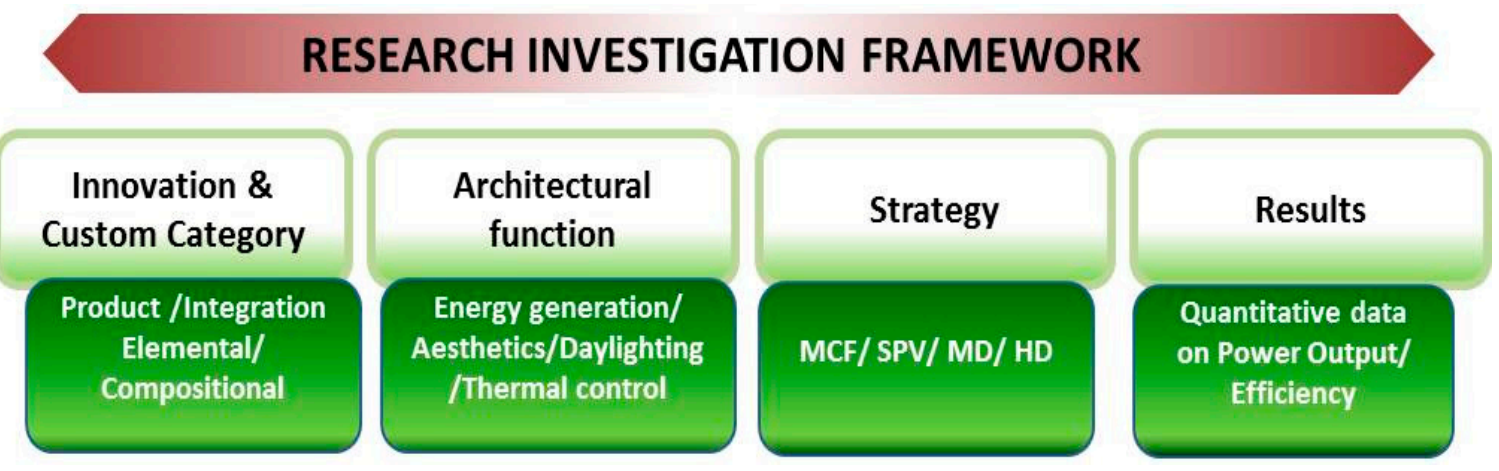

Figure 3. Research investigation framework. Source: By Authors.

1. Innovation and Custom Category: Product/Integration/Elemental/Compositional

This establishes whether customization is the design of a new product or a developed system of integration. Next, the identification of the customization level with regards to the aspect of the BIPV façade for which parametric variation was investigated. In this regard, several other authors suggest that a sub-division of BIPV exists by its constitution, being the elements that make up the modules and the composition that makes up the façade $[35,38,39,58,60]$. 
- The Elemental Level: this represents the breakdown of a BIPV module into various components i.e., the solar cells, frame, glass and other protective layers; reflecting customization of cell or glass or layer type; colors or efficiencies.

- The Compositional Level: this represents the composition of the cells of the BIPV module (module-level), relating to cell spacing and the modules of the BIPV façade (façade-level), relating to tilt angle or spacing from wall for example.

2. Customization strategy: Standard/Custom/Module/Façade design manipulation

In each of the studies various strategies have been employed to customize the BIPV façade. This section helps to provide an inventory of various strategies, categorization for further analysis, possible requirements, limitations and challenges, as well as directions for possible improvements.

These groups are;

- Systematic Parametric Variation (SPV): iterative parametric changes to reach an optimum goal

- Modification of Conventional Features (MCF): modification of conventional BIPV parts

- Enhanced Design Modularization (EDM): upgrade of BIPV façade types into unique modules

- Compositional Modification and Hybridization (CMH): combination of special materials with BIPV

3. Architectural function: energy generation/aesthetics/daylighting/thermal control

This section represents the stated, implied and potential functions of the custom BIPV façade in each study. It informs the specific custom function and provides justification to debate the sustained multi-functional advantage of BIPV. It also indicates if a connection exists between the customization category and level, and the potential architectural function.

4. Results: Power Output/Cell efficiency/Heating or Cooling loads

As the focus of this review is to validate the potential of BIPV customization as a solution to standard BIPV challenges, we also extracted the specific qualitative or quantitative data from the studies as made available. In some cases data on power output of BIPV façade output was provided which was;

- A comparison with a base case (standard BIPV);

- Hot climate results as representative of intense scenarios (where multiple climatic data was presented), or

- Highest output (where optimization based on parametric variation was investigated)

Table 4 details the investigated cases based on the research investigation framework explained above. It presents a concise summary to reflect how each study addressed BIPV customization to meet certain pre-defined objectives. All deductions from made from the experimental investigations were synthesized and analyzed in the discussion that follows the table. 
Table 4. Research investigations on BIPV façade customization.

\begin{tabular}{|c|c|c|c|c|c|c|c|}
\hline \multirow[b]{2}{*}{ Reference } & \multirow{2}{*}{$\begin{array}{c}\text { Country of Study } \\
\text { (BIPV Location on } \\
\text { Façade) }\end{array}$} & \multicolumn{5}{|c|}{ Deductions from Experimental Investigations } & \multirow[b]{2}{*}{ Research Results } \\
\hline & & Objective & $\begin{array}{c}\text { Custom Category/Class } \\
\text { of Study }\end{array}$ & $\begin{array}{c}\text { Customization Level } \\
\text { Investigated }\end{array}$ & Strategy (Description) & $\begin{array}{c}\text { Architectural } \\
\text { Potential }\end{array}$ & \\
\hline [51] & Taiwan (Wall) & $\begin{array}{l}\text { Development and } \\
\text { analysis of a } \\
\text { full-colour PV module }\end{array}$ & $\begin{array}{l}\text { Product/Design and } \\
\text { fabrication }\end{array}$ & $\begin{array}{l}\text { Elemental (Full-colour } \\
\text { and monochromatic } \\
\text { coloration of module } \\
\text { parts) }\end{array}$ & $\begin{array}{c}\text { Modification of } \\
\text { conventional features (MCF) } \\
\text { (Color image on } \\
\text { backsheetglass with applied } \\
\text { grayscale mask) }\end{array}$ & $\begin{array}{l}\text { Energy generation; } \\
\text { Aesthetics }\end{array}$ & $\begin{array}{c}\text { Short Current density: } 0-14 \% \\
\text { reduction } \\
\text { Cell efficiency : } \\
\text { drop to max of } 10 \% \\
\text { Power: } 14.2 \% \text { reduction }\end{array}$ \\
\hline [53] & $\begin{array}{l}\text { Switzerland (External } \\
\text { Device) }\end{array}$ & $\begin{array}{l}\text { Design, fabrication } \\
\text { and testing of an } \\
\text { adaptive solar façade }\end{array}$ & $\begin{array}{c}\text { Product \& } \\
\text { Integration/Design and } \\
\text { fabrication; Performance } \\
\text { Optimisation; } \\
\text { Architectural } \\
\text { Integration }\end{array}$ & $\begin{array}{c}\text { Compositional } \\
\text { @Façade-level } \\
\text { (dynamic façade } \\
\text { patterns and flexible } \\
\text { tilt angle) }\end{array}$ & $\begin{array}{c}\text { Enhanced design } \\
\text { modularization (EDM) } \\
\text { (Highly modular dynamic } \\
\text { BIPV façade with a suitable } \\
\text { support structure, tracking } \\
\text { and control systems) }\end{array}$ & $\begin{array}{l}\text { Energy generation; } \\
\text { Thermal Control; } \\
\text { Energy saving; } \\
\text { Aesthetics }\end{array}$ & $\begin{array}{c}\text { Power: } 36 \% \text { increase } \\
\text { Total energy savings: } \\
31 \% \text { increase } \\
\text { Energy consumption: } \\
8.9 \% \text { decrease } \\
\mathrm{CO}_{2} \text { offset: } 15.3 \mathrm{~kg} \mathrm{CO} \text {-eq per } \\
\text { year based on the European } \\
\text { Union grid mix. }\end{array}$ \\
\hline [80] & Austria (Glazing) & $\begin{array}{l}\text { Plasmonic coloring on } \\
\text { c-Si PV modules }\end{array}$ & $\begin{array}{l}\text { Product/Design and } \\
\text { fabrication }\end{array}$ & $\begin{array}{l}\text { Elemental (Cell } \\
\text { coloration) }\end{array}$ & $\begin{array}{c}\text { MCF; (Silver film } \\
\text { deposition on c-Si modules } \\
\text { with Ag thermal annealing.) }\end{array}$ & $\begin{array}{l}\text { Energy generation; } \\
\text { Aesthetics }\end{array}$ & $\begin{array}{c}\text { Short circuit current: average } \\
\text { of } 10.7 \% \text { reduction } \\
\text { Open circuit voltage: average } \\
\text { of } 1.1 \% \text { increase } \\
\text { Fill factor: } \\
\text { average of } 3.07 \% \text { increase } \\
\text { Maximum Power/Efficiency: } \\
\text { average of } 8.3 \% \text { reduction }\end{array}$ \\
\hline \multirow[t]{2}{*}{ [81] } & \multirow[t]{2}{*}{$\begin{array}{c}\text { South Korea (External } \\
\text { Shading) }\end{array}$} & $\begin{array}{l}\text { Application of } \\
\text { layering effects to a } \\
\text { BIPV façade }\end{array}$ & $\begin{array}{l}\text { Product/Design and } \\
\text { fabrication; } \\
\text { Architectural } \\
\text { Integration }\end{array}$ & $\begin{array}{l}\text { Compositional } \\
\text { @Module-level } \\
\text { (Coloration of } \\
\text { backsheet and Cell } \\
\text { arrangement) }\end{array}$ & $\begin{array}{l}\text { EDM (Layered effects to } \\
\text { BIPV module: unique } \\
\text { architectural finishing of } \\
\text { glass sheets, coloration of } \\
\text { backsheet with patterned } \\
\text { cell arrangement.) }\end{array}$ & $\begin{array}{l}\text { Energy generation; } \\
\text { Daylighting; } \\
\text { Aesthetics }\end{array}$ & \multirow{2}{*}{$\begin{array}{c}\text { Architectural layering and } \\
\text { modularization approach } \\
\text { enabled application and } \\
\text { adaptation of the described } \\
\text { effects specifically developed } \\
\text { to meet unique requests from } \\
\text { clients; } \\
\text { No performance data was } \\
\text { available. }\end{array}$} \\
\hline & & $\begin{array}{l}\text { Modular retrofitting of } \\
\text { a BIPV façade }\end{array}$ & $\begin{array}{l}\text { Integration/Architectural } \\
\text { Integration }\end{array}$ & $\begin{array}{l}\text { Compositional } \\
\text { @façade-level (tilt } \\
\text { angle) }\end{array}$ & $\begin{array}{c}\text { EDM (Modular retrofit and } \\
\text { prototyping based on } \\
\text { design of conventional } \\
\text { façades) }\end{array}$ & $\begin{array}{l}\text { Energy generation; } \\
\text { Daylighting; } \\
\text { Aesthetics }\end{array}$ & \\
\hline [63] & $\begin{array}{l}\text { Switzerland } \\
\text { (Cladding) }\end{array}$ & $\begin{array}{l}\text { Retrofitting of a } \\
\text { prototype residential } \\
\text { block with BIPV }\end{array}$ & $\begin{array}{l}\text { Integration/Architectural } \\
\text { Integration }\end{array}$ & $\begin{array}{l}\text { Elemental (Cell } \\
\text { transparency); } \\
\text { Compositional } \\
\text { @Façade-level } \\
\text { (Module position) }\end{array}$ & $\begin{array}{l}\text { EDM (adaptation of BIPV } \\
\text { typologies to blend with } \\
\text { convemtional facade } \\
\text { prototypes) }\end{array}$ & $\begin{array}{l}\text { Energy generation; } \\
\text { Thermal control; } \\
\text { Daylighting; } \\
\text { Retrofitting; } \\
\text { Aesthetics }\end{array}$ & $\begin{array}{l}\text { No extra complexity recorded } \\
\text { in application of the method } \\
\text { and façade construction. } \\
\text { Qualitative assessment of } \\
\text { interviewed professional } \\
\text { adjudge that aesthetical } \\
\text { aspects as positive. }\end{array}$ \\
\hline
\end{tabular}


Table 4. Cont.

\begin{tabular}{|c|c|c|c|c|c|c|c|}
\hline \multirow[b]{2}{*}{ Reference } & \multirow{2}{*}{$\begin{array}{c}\text { Country of Study } \\
\text { (BIPV Location on } \\
\text { Façade) }\end{array}$} & \multicolumn{5}{|c|}{ Deductions from Experimental Investigations } & \multirow[b]{2}{*}{ Research Results } \\
\hline & & Objective & $\begin{array}{c}\text { Custom Category/Class } \\
\text { of Study }\end{array}$ & $\begin{array}{l}\text { Customization Level } \\
\text { Investigated }\end{array}$ & Strategy (Description) & $\begin{array}{l}\text { Architectural } \\
\text { Potential }\end{array}$ & \\
\hline [82] & Korea (Window) & $\begin{array}{l}\text { Colored a-Si:H } \\
\text { transparent solar cells } \\
\text { employing ultrathin } \\
\text { transparent } \\
\text { multi-layered } \\
\text { electrodes. }\end{array}$ & $\begin{array}{l}\text { Product/Performance } \\
\text { and Optimization; } \\
\text { Architectural } \\
\text { Integration }\end{array}$ & $\begin{array}{l}\text { Elemental (Electrode } \\
\text { and Backsheet } \\
\text { transparency, Colour } \\
\text { variability) }\end{array}$ & $\begin{array}{c}\text { EDM; systematic } \\
\text { parametric variation (SPV); } \\
\text { MCF (Transparent } \\
\text { multi-layered electrodes } \\
\text { (TMEs) with customizable } \\
\text { coloration of optoelectronic } \\
\text { controlling layer (OCL) }\end{array}$ & $\begin{array}{l}\text { Energy generation; } \\
\text { Aesthetics; } \\
\text { Daylighting }\end{array}$ & $\begin{array}{c}\text { Cell Efficiency: average of } \\
6.36 \% \text { at } 23.5 \% \text { average } \\
\text { transmittance with TME } \\
\text { @ } 500-800 \mathrm{~nm} \\
\text { Ave Open circuit voltage: } 0.8 \mathrm{~V} \\
\text { Ave Fill factor: } 54.66 \%\end{array}$ \\
\hline [83] & $\begin{array}{l}\text { China (Window \& } \\
\text { Double Skin Façade) }\end{array}$ & $\begin{array}{l}\text { Comparison of energy } \\
\text { performance between } \\
\text { PV double skin } \\
\text { façades and PV } \\
\text { insulating glass units }\end{array}$ & $\begin{array}{l}\text { Product/Design and } \\
\text { fabrication; Performance } \\
\text { and Optimization; } \\
\text { Architectural } \\
\text { Integration }\end{array}$ & $\begin{array}{c}\text { Compositional } \\
\text { @Module-level } \\
\text { (Module Position, Air } \\
\text { gap) }\end{array}$ & $\begin{array}{l}\text { MCF; SPV; (Regulation of } \\
\text { air gap) }\end{array}$ & $\begin{array}{l}\text { Energy generation; } \\
\text { Thermal control; } \\
\text { Daylighting; } \\
\text { Energy saving; } \\
\text { Aesthetics }\end{array}$ & $\begin{array}{c}\text { Ave. SHGCs: } 0.152 \text { (PV-DSF) } \\
\text { and 0.238 (PV-IGU) } \\
\text { Ave. U-value: } 2.535 \mathrm{~W} / \mathrm{m}^{2} \mathrm{~K} \\
\text { (PV-DSF)and } 2.281 \mathrm{~W} / \mathrm{m}^{2} \mathrm{~K} \\
\text { (PV-IGU) } \\
\text { Conversion efficiency of } \\
\text { PV-DSF is 1.8\% better than } \\
\text { PV-IGU } \\
\text { Approx. power output: } \\
0.01-0.3 \mathrm{kWh} \text { (PV-DSF); } \\
0.01-0.32 \mathrm{kWh} \text { (PV-IGU) } \\
\text { Energy Saving potential: 28.4\% } \\
\text { (PV-DSF) and } 30 \% \text { (PV-IGU) }\end{array}$ \\
\hline [84] & $\begin{array}{l}\text { China (Double Skin } \\
\text { Façade) }\end{array}$ & $\begin{array}{c}\text { Overall energy } \\
\text { performance of an a-si } \\
\text { based photovoltaic } \\
\text { double-skin façade }\end{array}$ & $\begin{array}{l}\text { Integration/Design and } \\
\text { fabrication; Performance } \\
\text { and optimization; } \\
\text { Architectural } \\
\text { Integration; }\end{array}$ & $\begin{array}{c}\text { Compositional } \\
\text { @Façade-level } \\
\text { (Ventilation mode) }\end{array}$ & $\begin{array}{c}\text { MCF; SPV; (Change in } \\
\text { ventilated modes for } \\
\text { PV-DSF) }\end{array}$ & $\begin{array}{l}\text { Energy generation; } \\
\text { Thermal control }\end{array}$ & $\begin{array}{c}\text { Ave SHGC: } \\
0.14 \text { (Non-Ventilated), } \\
0.15 \text { (Naturally-Ventilated), } \\
0.125 \text { (Ventilated) } \\
\text { U-value: } \\
3.3 \text { (Non-Ventilated), } \\
3.7 \text { (Naturally-Ventilated), } \\
4.65 \text { (Ventilated) }\end{array}$ \\
\hline [85] & $\begin{array}{l}\text { Switzerland (Window } \\
\text { \& Wall) }\end{array}$ & $\begin{array}{c}\text { Performance } \\
\text { investigation of } \\
\text { selected BIPV façade } \\
\text { types. }\end{array}$ & $\begin{array}{c}\text { Product \& } \\
\text { Integration/Design and } \\
\text { fabrication; Performance } \\
\text { and optimization; } \\
\text { Architectural } \\
\text { Integration }\end{array}$ & $\begin{array}{c}\text { Elemental (Cell } \\
\text { technology, cell } \\
\text { transparency); } \\
\text { Compositional } \\
\text { @Module-level \& } \\
\text { Façade-level (Module } \\
\text { Position, Air gap, Tilt } \\
\text { angle) }\end{array}$ & $\begin{array}{l}\text { SPV; Variation of BIPV } \\
\text { module position and } \\
\text { ventilation mode }\end{array}$ & $\begin{array}{l}\text { Energy generation } \\
\text { Thermal control } \\
\text { Daylighting } \\
\text { Shading Aesthetics }\end{array}$ & $\begin{array}{c}\text { Approx. power output: } \\
3-11 \mathrm{kWh}\left(\mathrm{c}-\mathrm{Si} @ 3^{\circ}\right) ; \\
2.5-8 \mathrm{kWh}\left(\mathrm{c}-\mathrm{Si} @ 90^{\circ}\right) ; \\
0.6-2.1 \mathrm{kWh}\left(\mathrm{a}-\mathrm{Si} @ 30^{\circ}\right) ; \\
0.5-1.45 \mathrm{kWh}\left(\mathrm{a}-\mathrm{Si} @ 90^{\circ}\right) ; 0.8-2 \\
\text { kWh (a-Si @990-ventilated) }\end{array}$ \\
\hline
\end{tabular}


Table 4. Cont.

\begin{tabular}{|c|c|c|c|c|c|c|c|}
\hline \multirow[b]{2}{*}{ Reference } & \multirow{2}{*}{$\begin{array}{c}\text { Country of Study } \\
\text { (BIPV Location on } \\
\text { Façade) }\end{array}$} & \multicolumn{5}{|c|}{ Deductions from Experimental Investigations } & \multirow[b]{2}{*}{ Research Results } \\
\hline & & Objective & $\begin{array}{c}\text { Custom Category/Class } \\
\text { of Study }\end{array}$ & $\begin{array}{l}\text { Customization Level } \\
\text { Investigated }\end{array}$ & Strategy (Description) & $\begin{array}{c}\text { Architectural } \\
\text { Potential }\end{array}$ & \\
\hline [86] & China (Window) & $\begin{array}{l}\text { Assessment of energy } \\
\text { performance of } \\
\text { semi-transparent PV } \\
\text { insulating glass units }\end{array}$ & $\begin{array}{c}\text { Product \& } \\
\text { Integration/Design and } \\
\text { fabrication; Performance } \\
\text { and optimization; } \\
\text { Architectural } \\
\text { Integration }\end{array}$ & $\begin{array}{c}\text { Elemental (Backsheet); } \\
\text { Compositional } \\
\text { @Façade-level (Air } \\
\text { gap) }\end{array}$ & $\begin{array}{l}\text { MCF; SPV; (Variation of air } \\
\text { gap and backsheet material) }\end{array}$ & $\begin{array}{l}\text { Energy generation; } \\
\text { Thermal control; } \\
\text { Daylighting; } \\
\text { Energy saving }\end{array}$ & $\begin{array}{c}\text { Ave. PV temp: } 23-42{ }^{\circ} \mathrm{C} \text { Ave. } \\
\text { Daylight illuminance: } \\
\text { 0-360 lux } \\
\text { Ave. Heat gain: } \\
\text {-12.5-165 W/m² } \\
\text { Power output @ air gap: } \\
67.41 \mathrm{kWh} @ 3 \mathrm{~mm} ; \\
67.35 \mathrm{kWh} @ 6 \mathrm{~mm} ; \\
67.32 \mathrm{kWh} @ 9 \mathrm{~mm} ; \\
67.3 \mathrm{kWh} @ 12 \mathrm{~mm} ; \\
67.29 \mathrm{kWh} @ 15 \mathrm{~mm} \\
\text { Power output @backsheet type } \\
\text { 67.32 kWh (Clear glass); } \\
66.84 \mathrm{kWh} \text { (Low-e glass); } \\
\text { 67.4 kWh (Low iron glass): } \\
\text { 67.2 kWh (Tinted glass) }\end{array}$ \\
\hline [87] & USA (Window) & $\begin{array}{c}\text { Energy benefits from } \\
\text { semi-transparent BIPV } \\
\text { window and } \\
\text { daylight-dimming } \\
\text { systems }\end{array}$ & $\begin{array}{c}\text { Product \& } \\
\text { Integration/Performance } \\
\text { and Optimization; } \\
\text { Architectural } \\
\text { Integration }\end{array}$ & $\begin{array}{c}\text { Elemental (Cell } \\
\text { transparency and } \\
\text { efficiency); } \\
\text { Compositional } \\
\text { @Façade-level } \\
\text { (Orientation and } \\
\text { WWR) }\end{array}$ & $\begin{array}{c}\text { MCF; SPV; (Use of a DOE-2 } \\
\text { based calculation algorithm } \\
\text { simulations of } \\
\text { parameterised vaules) }\end{array}$ & $\begin{array}{l}\text { Energy generation; } \\
\text { Thermal control; } \\
\text { Daylighting; } \\
\text { Shading; Energy } \\
\text { savings }\end{array}$ & $\begin{array}{c}\text { Power output range on south } \\
\text { façade/month: } 35.1-71.9 \mathrm{kWh} \\
\text { @6.65 efficiency, 40\% } \\
\text { transparency, } 48 \mathrm{~W} 46.4-95.4 \\
\text { kWh @8.82 efficiency, 20\% } \\
\text { transparency, } 64 \mathrm{~W} 52.4-107.2 \\
\text { kWh @9.91 efficiency, } 10 \% \\
\text { transparency, } 72 \mathrm{~W} \\
\text { Approx. Annual Power output } \\
\text { @WWR: } 1165 \mathrm{kWh} @ 10 \% ; 3496 \\
\text { kWh @30\%; } 8157 \text { @ } 370 \%\end{array}$ \\
\hline [88] & $\begin{array}{c}\text { Canada (Double Skin } \\
\text { Façade) }\end{array}$ & $\begin{array}{l}\text { Patterns of façade } \\
\text { system design for } \\
\text { enhanced energy } \\
\text { performance }\end{array}$ & $\begin{array}{c}\text { Product \& } \\
\text { Integration/Performance } \\
\text { and Optimization; } \\
\text { Architectural } \\
\text { Integration }\end{array}$ & $\begin{array}{l}\text { Compositional } \\
\text { @Module-level } \\
\text { (Module } \\
\text { placement/arrangement) }\end{array}$ & $\begin{array}{c}\text { MCF; SPV; EDM } \\
\text { (Manipulation of planar } \\
\text { geometry to induce increase } \\
\text { in solar capture) }\end{array}$ & $\begin{array}{l}\text { Energy generation; } \\
\text { Thermal control; } \\
\text { Aesthetics }\end{array}$ & $\begin{array}{l}\text { Comparison with base case: } \\
\text { Power Output: } 20-80 \% \\
\text { increase Heating load: about } \\
200 \% \text { increase (worst case) } \\
\text { Cooling load: about } 52 \% \\
\text { reduction (best case) } \\
\text { Peak electricity: peak spread of } \\
4-5 \mathrm{~h} \text {. }\end{array}$ \\
\hline [55] & Pakistan (Wall) & $\begin{array}{l}\text { Energy and Cost } \\
\text { Saving of a } \\
\text { Photovoltaic-Phase } \\
\text { Change Material } \\
\text { (PV-PCM) System }\end{array}$ & $\begin{array}{l}\text { Product/Design and } \\
\text { fabrication; Performance } \\
\text { and Optimization; Cost }\end{array}$ & $\begin{array}{c}\text { Elemental } \\
\text { (Phase-change } \\
\text { materials); } \\
\text { Compositional } \\
\text { @Module-level } \\
\text { (Module design) }\end{array}$ & $\begin{array}{l}\text { SPV;CHM; EDM (Passive } \\
\text { cooling of BIPV with } \\
\text { solid-liquid PCMs) }\end{array}$ & $\begin{array}{l}\text { Energy generation; } \\
\text { Thermal control }\end{array}$ & $\begin{array}{c}\text { Temperature drop: } \\
\text { 16\% (PV PCM-1); } \\
\text { 32.5\% (PV PCM-2) Ave energy } \\
\text { efficiency increase: 7\% (PV } \\
\text { PCM-1); } \\
\text { 10\% (PV PCM-2) }\end{array}$ \\
\hline
\end{tabular}


Table 4. Cont.

\begin{tabular}{|c|c|c|c|c|c|c|c|}
\hline \multirow[b]{2}{*}{ Reference } & \multirow{2}{*}{$\begin{array}{c}\text { Country of Study } \\
\text { (BIPV Location on } \\
\text { Façade) }\end{array}$} & \multicolumn{5}{|c|}{ Deductions from Experimental Investigations } & \multirow[b]{2}{*}{ Research Results } \\
\hline & & Objective & $\begin{array}{c}\text { Custom Category/Class } \\
\text { of Study }\end{array}$ & $\begin{array}{c}\text { Customization Level } \\
\text { Investigated }\end{array}$ & Strategy (Description) & $\begin{array}{l}\text { Architectural } \\
\text { Potential }\end{array}$ & \\
\hline [89] & China (Wall) & $\begin{array}{l}\text { Analysis and } \\
\text { monitoring results of a } \\
\text { BIPV façade using PV } \\
\text { ceramic tiles }\end{array}$ & $\begin{array}{l}\text { Product/Design and } \\
\text { fabrication; Performance } \\
\text { and Optimization; } \\
\text { Architectural } \\
\text { Integration }\end{array}$ & $\begin{array}{l}\text { Compositional } \\
\text { @Module-level } \\
\text { (Module } \\
\text { Position/Module } \\
\text { Arrangement) }\end{array}$ & $\begin{array}{l}\text { MCF(Replacement of } \\
\text { module backsheet with } \\
\text { ceramic tile) }\end{array}$ & $\begin{array}{l}\text { Energy generation; } \\
\text { Thermal control; } \\
\text { Aesthetics }\end{array}$ & $\begin{array}{l}\text { Ave. power output: } \\
15-72 \mathrm{kWh} \text { (east); } \\
15-65 \mathrm{kWh} \text { (West); } \\
1-72 \mathrm{kWh} \text { (south); } \\
0-18 \mathrm{kWh} \text { (North) }\end{array}$ \\
\hline [90] & $\begin{array}{l}\text { UAE (Double Skin } \\
\text { Façade) }\end{array}$ & $\begin{array}{l}\text { Performance and } \\
\text { energetic } \\
\text { improvements due to } \\
\text { installation of } \\
\text { semi-transparent PV } \\
\text { cells }\end{array}$ & $\begin{array}{c}\text { Product \& } \\
\text { Integration/Design and } \\
\text { fabrication; Performance } \\
\text { and Optimization; } \\
\text { Architectural } \\
\text { Integration }\end{array}$ & $\begin{array}{c}\text { Compositional } \\
\text { @Module-level \& } \\
\text { Façade-level (Number } \\
\text { of glass layers, } \\
\text { Ventilation mode) }\end{array}$ & $\begin{array}{l}\text { MCF; SPV; (Application of } \\
\text { alternate ventilation modes } \\
\text { and number of glass layers) }\end{array}$ & $\begin{array}{l}\text { Energy generation; } \\
\text { Cladding }\end{array}$ & $\begin{array}{l}\text { Sensible cooling energy need } \\
\text { reduction: } 1.5 \% \text { (DSF forced vs. } \\
\text { natural), } 1.9 \% \text { (Single Layer } \\
\text { forced vs. natural) } \\
\text { Peak power drop: } 4 \% \text { (DSF } \\
\text { forced vs. natural), } 2.3 \% \\
\text { (Single Layer forced vs. } \\
\text { natural) } \\
\text { Annual energy production } \\
\text { increased by 2.5 (DSF) } 6 \% \\
\text { (Single Layer) }\end{array}$ \\
\hline [17] & $\begin{array}{c}\text { USA (Ventilated } \\
\text { Double Skin Façade) }\end{array}$ & $\begin{array}{l}\text { Numerical } \\
\text { investigation of the } \\
\text { energy saving } \\
\text { potential of a } \\
\text { semi-transparent } \\
\text { photovoltaic } \\
\text { double-skin façade }\end{array}$ & $\begin{array}{c}\text { Product \& } \\
\text { Integration/Performance } \\
\text { and Optimization; } \\
\text { Architectural } \\
\text { Integration }\end{array}$ & $\begin{array}{l}\text { Compositional } \\
\text { @Façade-level (Air } \\
\text { gap, Orientation) }\end{array}$ & $\begin{array}{c}\text { MCF; SPV; EDM } \\
\text { (Application of alternate air } \\
\text { gaps and orientation in } \\
\text { office room prototype room) }\end{array}$ & $\begin{array}{l}\text { Energy generation; } \\
\text { Thermal control; } \\
\text { Daylighting; } \\
\text { Shading }\end{array}$ & $\begin{array}{c}\text { Approx. ave. electricity use: } \\
300 \mathrm{kWh}(100 \mathrm{~mm}) ; \\
310 \mathrm{kWh}(200 \mathrm{~mm}) ; 285 \mathrm{kWh} \\
(400 \mathrm{~mm}) ; 270 \mathrm{kWh}(600 \mathrm{~mm}) \\
\text { With } 400 \mathrm{~mm}: \\
\text { Max power output range on } \\
\text { south façade } / \text { month: } \\
10.3 \mathrm{kWh} \text { (June)-20 } \mathrm{kWh} \\
\text { (November) Approx. Annual } \\
\text { Energy output: } 48 \mathrm{kWh} / \mathrm{m}^{2} \\
\text { (East), } 64 \mathrm{kWh} / \mathrm{m}^{2} \text { (South), } \\
54 \mathrm{kWh} / \mathrm{m}^{2} \text { (West) } \\
\text { Approx. cooling need: } \\
18-270 \text { MJ Approx. heating } \\
\text { need: } 0-35 \mathrm{MJ} \\
\text { Ave. daylighting } \\
\text { illuminance } / \mathrm{mon} \text { th: } \\
130-300 \text { lux } \\
\text { Observed } 50 \% \text { less net } \\
\text { electricity that conventional } \\
\text { glazing systems }\end{array}$ \\
\hline
\end{tabular}


Table 4. Cont.

\begin{tabular}{|c|c|c|c|c|c|c|c|}
\hline \multirow[b]{2}{*}{ Reference } & \multirow{2}{*}{$\begin{array}{l}\text { Country of Study } \\
\text { (BIPV Location on } \\
\text { Façade) }\end{array}$} & \multicolumn{5}{|c|}{ Deductions from Experimental Investigations } & \multirow[b]{2}{*}{ Research Results } \\
\hline & & Objective & $\begin{array}{c}\text { Custom Category/Class } \\
\text { of Study }\end{array}$ & $\begin{array}{c}\text { Customization Level } \\
\text { Investigated }\end{array}$ & Strategy (Description) & $\begin{array}{c}\text { Architectural } \\
\text { Potential }\end{array}$ & \\
\hline [91] & $\begin{array}{l}\text { Slovakia (Ventilated } \\
\text { PV Façade) }\end{array}$ & $\begin{array}{c}\text { Thermal Performance } \\
\text { of a Ventilated PV } \\
\text { Façade Coupled with } \\
\text { PCM }\end{array}$ & $\begin{array}{c}\text { Product \& } \\
\text { Integration/Design, } \\
\text { Performance and } \\
\text { Optimization; } \\
\text { Architectural } \\
\text { Integration } \\
\end{array}$ & $\begin{array}{l}\text { Compositional } \\
\text { @Module-level } \\
\text { (Module } \\
\text { design—addition of } \\
\text { PCM) }\end{array}$ & $\begin{array}{l}\text { CMH; SPV (Hybridisation } \\
\text { of BIPV with PCM layer) }\end{array}$ & Thermal control & $\begin{array}{l}\text { PV temp decrease: up to } 20^{\circ} \mathrm{C} \\
\text { Peak temp. shift: } \\
\text { more than } 5 \mathrm{~h}\end{array}$ \\
\hline [92] & $\begin{array}{c}\text { France (Ventilated PV } \\
\text { Façade) }\end{array}$ & $\begin{array}{l}\text { Experimental } \\
\text { evaluation of a } \\
\text { naturally ventilated } \\
\text { PV double-skin } \\
\text { building envelope in } \\
\text { real operating } \\
\text { conditions }\end{array}$ & $\begin{array}{c}\text { Product \& } \\
\text { Integration/Design and } \\
\text { fabrication; Performance } \\
\text { and Optimization; } \\
\text { Architectural } \\
\text { Integration }\end{array}$ & $\begin{array}{l}\text { Compositional } \\
\text { @Module-level } \\
\text { (Module arrangement) }\end{array}$ & $\begin{array}{l}\text { MCF; SPV (Utilising the } \\
\text { stack effect to cool a } \\
\text { prototype pleated PV } \\
\text { double façade) }\end{array}$ & $\begin{array}{l}\text { Energy generation; } \\
\text { Thermal control; } \\
\text { Daylighting; } \\
\text { Shading; } \\
\text { Aesthetics }\end{array}$ & $\begin{array}{l}\text { Approx. Peak power output } \\
\text { per plane: } 165 \mathrm{~kW} \text { (Bloc1); } \\
200 \mathrm{~kW} \text { (Bloc2); } 210 \mathrm{~kW} \text { (Bloc3) } \\
\text { Prismatic configuration was } \\
\text { chosen to compensate for } \\
\text { façade azimuth- } \\
\text { overshadowing in part; } \\
\text { improvement in electrical } \\
\text { performance by a more } \\
\text { favorable orientation of solar } \\
\text { cells }\end{array}$ \\
\hline [93] & UAE (Window Blinds) & $\begin{array}{l}\text { Energy, Cooling and } \\
\text { Cost analysis of BIPV } \\
\text { blind system }\end{array}$ & $\begin{array}{c}\text { Product \& } \\
\text { Integration/Design and } \\
\text { fabrication; Performance } \\
\text { and Optimization; } \\
\text { Architectural } \\
\text { Integration; Cost }\end{array}$ & $\begin{array}{c}\text { Elemental (cell } \\
\text { technology); } \\
\text { Compositional } \\
\text { (Module position) }\end{array}$ & $\begin{array}{l}\text { EDM; SPV (Prototyping } \\
\text { based on conventional } \\
\text { façade design component) }\end{array}$ & $\begin{array}{l}\text { Energy generation; } \\
\text { Thermal control; } \\
\text { Cost issues }\end{array}$ & $\begin{array}{c}\text { Ave. power output: } \\
41.55 \mathrm{kWh} / \mathrm{m}^{2}(\mathrm{c}-\mathrm{Si}) ; \\
43.22 \mathrm{kWh} / \mathrm{m}^{2}(\mathrm{a}-\mathrm{Si}) \\
\text { Cooling load Energy Saved: } \\
7.11 \mathrm{kWh} / \mathrm{m}^{2}(\mathrm{c}-\mathrm{Si}) ; \\
6.89 \mathrm{kWh} / \mathrm{m}^{2}(\mathrm{a}-\mathrm{Si})\end{array}$ \\
\hline [64] & $\begin{array}{l}\text { China (PV-Blinds in } \\
\text { Double Skin Façade) }\end{array}$ & $\begin{array}{l}\text { Comparative study on } \\
\text { thermal performance } \\
\text { evaluation of a new } \\
\text { double skin façade } \\
\text { system integrated } \\
\text { with photovoltaic } \\
\text { blinds }\end{array}$ & $\begin{array}{c}\text { Product \& } \\
\text { Integration/Design and } \\
\text { fabrication; Performance } \\
\text { and Optimization; } \\
\text { Architectural } \\
\text { Integration }\end{array}$ & $\begin{array}{c}\text { Compositional } \\
\text { @Module-level } \\
\text { (Module Position/Tilt } \\
\text { angle) }\end{array}$ & $\begin{array}{l}\text { SPV (Experimentation on } \\
\text { different system ventilation } \\
\text { modes and blind } \\
\text { parameters) }\end{array}$ & $\begin{array}{l}\text { Energy generation; } \\
\text { Thermal control; } \\
\text { Daylighting }\end{array}$ & $\begin{array}{c}\text { Approx. SGHC peak }(@ 4.5 \mathrm{~cm} \\
\text { spacing): } 0.75\left(30^{\circ}\right) ; 0.95\left(45^{\circ}\right) ; \\
0.97\left(60^{\circ}\right) ;(\text { based on } \\
\text { ventilation mode): } 0.499 \\
\text { (Mechanical); } 0.531 \text { (Natural) } \\
\text { About } 12.16 \% \text { and } 25.57 \% \\
\text { compared with reference DSF } \\
\text { cases }\end{array}$ \\
\hline
\end{tabular}


Table 4. Cont.

\begin{tabular}{|c|c|c|c|c|c|c|c|}
\hline \multirow[b]{2}{*}{ Reference } & \multirow{2}{*}{$\begin{array}{c}\text { Country of Study } \\
\text { (BIPV Location on } \\
\text { Façade) }\end{array}$} & \multicolumn{5}{|c|}{ Deductions from Experimental Investigations } & \multirow[b]{2}{*}{ Research Results } \\
\hline & & Objective & $\begin{array}{c}\text { Custom Category/Class } \\
\text { of Study }\end{array}$ & $\begin{array}{l}\text { Customization Level } \\
\text { Investigated }\end{array}$ & Strategy (Description) & $\begin{array}{l}\text { Architectural } \\
\text { Potential }\end{array}$ & \\
\hline [94] & $\begin{array}{l}\text { China (Ventilated } \\
\text { Double Skin Façade) }\end{array}$ & $\begin{array}{c}\text { Thermal performance } \\
\text { of a photovoltaic wall } \\
\text { mounted on a } \\
\text { multi-layer façade }\end{array}$ & $\begin{array}{l}\text { Integration/Performance } \\
\text { and Optimization; } \\
\text { Architectural } \\
\text { Integration }\end{array}$ & $\begin{array}{c}\text { Compositional } \\
\text { @Facade-level } \\
\text { (ventilation mode) }\end{array}$ & $\begin{array}{l}\text { SPV (Mathematical } \\
\text { modelling and variation of } \\
\text { ventilation modes) }\end{array}$ & $\begin{array}{l}\text { Energy generation; } \\
\text { Thermal control }\end{array}$ & $\begin{array}{c}\text { Ave SHGC: } \\
0.14 \text { (Non-Ventilated), } \\
0.15 \text { (Naturally-Ventilated), } \\
0.125 \text { (Ventilated) } \\
\text { U-value: } 3.3 \text { (Non-Ventilated), } \\
3.7 \text { (Naturally-Ventilated), } \\
4.65 \text { (Ventilated) }\end{array}$ \\
\hline [52] & (Glazing) & $\begin{array}{l}\text { Aesthetic } \\
\text { improvement of PV } \\
\text { for Building } \\
\text { integration } \\
\text { Encapsulants }\end{array}$ & $\begin{array}{l}\text { Product/Design and } \\
\text { fabrication; } \\
\text { Architectural } \\
\text { Integration }\end{array}$ & $\begin{array}{c}\text { Elemental } \\
\text { (Encapsulant material) }\end{array}$ & $\begin{array}{l}\text { MCF (Coloration of } \\
\text { encapsulant material using } \\
\text { florescence dyes) }\end{array}$ & $\begin{array}{l}\text { Energy generation; } \\
\text { Aesthetics }\end{array}$ & $\begin{array}{l}\text { Power output increase: } \\
2.0 \% \text { (Clear Sylgard 184); } \\
2.5 \% \text { (Red } 100 \text { ppm Lumogen } \\
\text { dye in Sylgard 184) }\end{array}$ \\
\hline [95] & Italy (Glassblocks) & $\begin{array}{c}\text { Evaluation of } \\
\text { prototype BIPV } \\
\text { optical performance }\end{array}$ & $\begin{array}{l}\text { Product/Design and } \\
\text { Fabrication; } \\
\text { Performance } \\
\text { optimization }\end{array}$ & $\begin{array}{c}\text { Compositional } \\
\text { @Module-level } \\
\text { (position of solar cells) }\end{array}$ & $\begin{array}{l}\text { CMH; EDM (Prototyping } \\
\text { based on conventional } \\
\text { façade design component) }\end{array}$ & $\begin{array}{l}\text { Energy generation; } \\
\text { Aesthetics; } \\
\text { Daylighting; } \\
\text { Thermal Control }\end{array}$ & $\begin{array}{c}\text { Power output reductions: } \\
\text { 19.67\% (DSSC Part of Surface); } \\
\text { 6.01\% (All of Surface); } \\
54.09 \% \text { (Interior of Surface); } \\
69.94 \% \text { (Middle of Block) }\end{array}$ \\
\hline [96] & Netherlands (Wall) & $\begin{array}{l}\text { Aesthetics } \\
\text { preservation BIPV } \\
\text { façade using Zigzag } \\
\text { geometry }\end{array}$ & $\begin{array}{l}\text { Product/Design and } \\
\text { Fabrication; } \\
\text { Architectural } \\
\text { integration }\end{array}$ & $\begin{array}{l}\text { Elemental (colour of } \\
\text { reflector layer); } \\
\text { Compositional } \\
\text { @Facade-level (tilt } \\
\text { angle) }\end{array}$ & $\begin{array}{c}\text { EDM; MCF; SPV } \\
\text { (Concealment of PV via } \\
\text { zigzag geometry to enhance } \\
\text { solar capture) }\end{array}$ & $\begin{array}{l}\text { Energy generation; } \\
\text { Aesthetics }\end{array}$ & $\begin{array}{c}\text { Monthly Power output: } \\
28.6 \mathrm{kWh} \text { (Grey), } 30.7 \mathrm{kWh} \\
\text { (White) Performance ratio } \\
\text { increase (ref. vertical panels): } \\
43.75 \% \text { (Grey), } 53.75 \% \text { (White) }\end{array}$ \\
\hline
\end{tabular}




\subsection{Assessment of BIPV Customization Parameters}

Table 4 shows that all the studies reviewed give focus to energy generation and architectural integration; most also focus on performance and optimization of the BIPV façade; few focus on cost and environmental issues. This is reminiscent of the general fact that a BIPV façade is primarily a building element with energy producing capability. Thus, its integration and optimization of its performance are significantly important. The country of study and BIPV façade type highlight the potentiality in a variety of countries and application in building location. The variety of objective and approach in the various studies was expected, and provided a broad spectrum to carry out the review. However, in order to provide a sensible analysis, categorization was done at each stage without bias to the original intent of the researchers.

\subsubsection{Innovation and Custom Category}

Statistically, nine of the cases focused on design of a custom BIPV product [51,52,55,80-83,89,95], only four focused on a customization in the integration process $[63,81,84,94]$, while 12 combined both product and integration concerns in their research $[17,53,63,64,85-88,90-93]$. This suggests that most custom BIPV façade products are designed with attention on the potential for proper architectural integration. Each approach is uniquely different, yet they meet the same goals of energy generation, aesthetics, and daylighting or thermal control. It is important to consolidate at this point the fact that conventional BIPV façades can provide some of these gains along with energy generation. However, these customized BIPV have the potential to out-perform standard types based on pre-design specifications and functionally-driven objectives, which emphasize these other benefits.

Regarding the customization level, four were purely elemental [51,52,80,82], eight were compositional at the module-level $[64,81,83,88,89,91,92,95]$, and five were compositional at the façade-level [17,53,81,84,94]; eight studies combined all of the levels $[55,82,85-87,90,93,96]$. Comparing elemental versus compositional level, studies can be more easily carried out using conventional PV modules without the requirement of a custom-designed module. As this will require less time to fabricate the test specimens, it is probable that compositional studies are thus preferred, and were thus more numerous. However, using conventional modules for customization suggests innovative and creative applications.

\subsubsection{Customization Strategy}

The studies showed varying levels of complexity in the strategies used to achieve the objective of customization. It is clear from the examples that this was achieved by an interdisciplinary approach to BIPV product design. It therefore suggests that the accomplishment of custom BIPV modules requires input across several disciplines. While this may be more demanding and expensive, it creates the opportunity for greater novelty and innovative ideas. Enhanced flexibility and variety was noticed in the strategic approach applied in custom BIPV integration studies.

In the investigated cases, three were SPV $[64,85,94]$, four were MCF $[51,52,80,89]$, four were $\operatorname{EDM}[53,63,81]$, and 14 combined two or more strategies [17,55,82-84,86-88,90-93,95,96]. Clear evidence thus presents a combination of various strategies is required to achieve BIPV façade customization. In the cases of combined strategies, most of the studies addressed customization at both an elemental and compositional level, reflecting a holistic approach. Furthermore, most of the studies in this class were carried out to address aesthetic or thermal control objectives. Deductively therefore, the combined strategy approach is preferred for BIPV façade customization as it covers various multi-dimensional issues in the design.

\subsubsection{Architectural Function}

All the studied cases showed interest in energy generation potential of the custom BIPV, but to varying degrees. With regards to the added functions, [17] studies addressed thermal control [17,53,63,83-89,91-95], [15] addressed aesthetics [17] and, [11] addressed daylighting functionality 
based on research objective or cell type selection as all a-Si applications permit some degree of light transmission $[7,63,64,82,83,85-87,92,95]$. Also, three addressed energy savings [53,83,87], four specifically on shading [85-87,92], and one on cladding [90] and cost [93].

The review shows that although all focused on energy generation of the custom BIPV façade, all focused also on at least one or more added function. More than half of the studies were on thermal control-in terms of added BIPV function; proving capture and reuse of PV thermal energy, as well as reduction of direct solar radiation to the interior. A sizeable number of the studies show a connection with the goal of improving the thermal control or aesthetic appeal of the product. It suggests that customization of BIPV products is in some way primarily driven by these two objectives. We observed that the architectural functions were achieved by all the classified strategies. The import of this finding is that categorization developed for this review of customization strategies for BIPV façades is justifiable, flexible and versatile in applicability.

\subsubsection{Results}

Performance data from the studies were varied and not reflective of comparisons with a conventional BIPV or a reference case in most cases. Were available, a $4-70 \%$ reduction related to power output was observed $[51,80,90,95]$ and a $2-80 \%$ increase $[52,53,55,96]$. It is important to observe that these studies used different strategies with different reference cases. As these studies were also in different climates it is not possible to make a general conclusion on these results. They are however representative of the fact that BIPV façade customization has potentials for performance improvements or otherwise based on the design and specifications

Of the studies related to thermal control with reference cases, 3 showed improvements in relation to power output while 1 showed reductions. Of the studies related aesthetics with reference cases, 4 showed improvements in relation to power output while 2 showed reductions. This suggests the in comparative situations, the process of customization can enhance thermal control and aesthetics with satisfactory performance related to power output.

\section{Challenges and Future Prospects}

Several challenges exist with the concept of BIPV customization in general and specific terms and several studies have outlined these barriers [24-34,97]. Firstly, BIPV itself is still in a technological developmental phase. Its full potential is yet to be maximized and studies argue that there are still design codes and standards for application that are not full developed $[24,28,30]$. This review has further brought to light the vast variations in strategies and approaches with BIPV façade customization. Developing a framework for analysis is thus potentially challenging and requires certain generalizations.

Specific to BIPV façade customization objectives, thermal control and aesthetics were identified as the most frequently studied. However, the several of strategies used in both cases required special manufacturing processes which are not yet standardized on a large scale. Thus, problems with cost, machinery, and standards exist. This scenario is worsened by the identified gap between the PV and building industry $[29,30,32]$; as the lack of willingness to adopt new technology can be a drawback for custom applications. Further research is required to standardize the assessment of custom BIPV and develop a model for evaluation of strategies. This review intended to identify the potentiality of BIPV customization but does not answer questions related to climatic or regional applications. Customization in relation to cost issues is another area that presents further research potential to yield clear evaluative data. The cost and efficiency of a BIPV system can be lowered by reducing PV module and component manufacturing costs, improving PV and other component efficiencies, and understanding whole life cycle costs $[21,98]$ in relation to local factors and the context when used a building skin [99].

A comparative analysis between research driven BIPV customization and commercial custom BIPV products is also required to reflect the quantitative and qualitative dimensions of the variations 
in performance and perception. The main bottleneck discovered during a BIPV study conducted in an European research project, was in the ability to communicate this enhanced value and the new possibilities to customers and thus justify the higher cost-generally an increment around 20\% [66]. Thus, custom BIPV potentials require proper communication of potentials to both the public and professionals.

\section{Conclusions}

This review strategically raises a theoretical background for a renewed focus on BIPV customization. It is clear that there are several experimental studies which engage in this strategy at one level or the other. Our findings indicate that BIPV façade customization can be carried out with significant advantages which include:

1. Flexibility and applicability at an elemental and compositional level

2. Versatility in development of both custom BIPV products and custom BIPV integration schemes

3. Multiple type strategies in single or combined scenarios can be used to achieve objectives

4. Increase in power output and performance is possible in a range of $2-80 \%$ based on design

5. Although, reduction in power output and performance occurs also at a range of $4-70 \%$ based on design

In summary, we conclude that BIPV façade customization can address some of the barriers with conventional BIPV façades relating to product efficiency and aesthetic design. It can also be a driver of enhanced innovative product design for architectural integration. The extensive research and global interest in BIPV over the last one decade is not likely to abate. Areas such as daylighting, self-cleaning PV glazing, aesthetics using color, form or shapes, concentrating BIPV, perovskite-based solar cells and solar trees are some of the emerging areas [36,45,100-103]. With shifting policies, government tariffs and policy changes, it will also be interesting to investigate the possibility of using demonstration projects in certain regions as a push for BIPV-wide acceptance. Such projects will be opportunities to communicate the significant benefits of BIPV customisation and advance its adoption.

Acknowledgments: The authors gratefully acknowledge financial support from the United Arab Emirates University towards this review as part of an on-going doctoral research.

Author Contributions: Daniel Efurosibina Attoye developed the concept and framework for investigation, carried out data collection and wrote the initial manuscript. Kheira Tabet Aoul and Ahmed Hassan verified the scholastic depth of the paper, carried out a critical review of the structure and content, and also supervised the analysis and findings of this work. All authors discussed the results and contributed to the final manuscript.

Conflicts of Interest: The authors declare no conflict of interest.

\section{References}

1. Nejat, P.; Jomehzadeh, F.; Taheri, M.M.; Gohari, M.; Majid, M.Z.A. A global review of energy consumption, $\mathrm{CO}_{2}$ emissions and policy in the residential sector (with an overview of the top ten $\mathrm{CO}_{2}$ emitting countries). Renew. Sustain. Energy Rev. 2015, 43, 843-862. [CrossRef]

2. World Energy Council (WEC). World Energy Resources 2013 Survey; World Energy Council: London, UK, 2013.

3. De la Cruz-Lovera, C.; Perea-Moreno, A.J.; de la Cruz-Fernández, J.L.; Alvarez-Bermejo, J.A.; Manzano-Agugliaro, F. Worldwide Research on Energy Efficiency and Sustainability in Public Buildings. Sustainability 2017, 9, 1294. [CrossRef]

4. Woodcock, J.; Edwards, P.; Tonne, C.; Armstrong, B.G.; Ashiru, O.; Banister, D.; Beevers, S.; Chalabi, Z.; Chowdhury, Z.; Cohen, A.; et al. Public health benefits of strategies to reduce greenhouse-gas emissions: Urban land transport. Lancet 2009, 374, 1930-1943. [CrossRef]

5. Adewuyi, A.O.; Awodumi, O.B. Renewable and non-renewable energy-growth-emissions linkages: Review of emerging trends with policy implications. Renew. Sustain. Energy Rev. 2017, 69, 275-291. [CrossRef]

6. Wang, F.; Wang, C.; Su, Y.; Jin, L.; Wang, Y.; Zhang, X. Decomposition Analysis of Carbon Emission Factors from Energy Consumption in Guangdong Province from 1990 to 2014. Sustainability 2017, 9, 274. [CrossRef] 
7. Rodhe, H. A comparison of the contribution of various gases to the greenhouse effect. Science 1990, $248,1217$. [CrossRef] [PubMed]

8. Lashof, D.A.; Ahuja, D.R. Relative contributions of greenhouse gas emissions to global warming. Nature 1990, 344, 529-531. [CrossRef]

9. Jiang, W.; Liu, J.; Liu, X. Impact of carbon quota allocation mechanism on emissions trading: An agent-based simulation. Sustainability 2016, 8, 826. [CrossRef]

10. Camanzi, L.; Alikadic, A.; Compagnoni, L.; Merloni, E. The impact of greenhouse gas emissions in the EU food chain: A quantitative and economic assessment using an environmentally extended input-output approach. J. Clean. Prod. 2017, 157, 168-176. [CrossRef]

11. Intergovernmental Panel on Climate Change (IPCC). Climate Change 2007: Synthesis Report; Intergovernmental Panel on Climate Change: Geneva, Switzerland, 2007; pp. 45-54.

12. Liu, W.Y.; Lin, C.C.; Chiu, C.R.; Tsao, Y.S.; Wang, Q. Minimizing the carbon footprint for the time-dependent heterogeneous-fleet vehicle routing problem with alternative paths. Sustainability 2014, 6, 4658-4684. [CrossRef]

13. Knera, D.; Knera, D.; Heim, D.; Heim, D. Application of a BIPV to cover net energy use of the adjacent office room. Manag. Environ. Qual. Int. J. 2016, 27, 649-662. [CrossRef]

14. Evola, G.; Margani, G. Renovation of apartment blocks with BIPV: Energy and economic evaluation in temperate climate. Energy Build. 2016, 130, 794-810. [CrossRef]

15. Jayathissa, P.; Luzzatto, M.; Schmidli, J.; Hofer, J.; Nagy, Z.; Schlueter, A. Optimising building net energy demand with dynamic BIPV shading. Appl. Energy 2017, 202, 726-735. [CrossRef]

16. Wong, P.W.; Shimoda, Y.; Nonaka, M.; Inoue, M.; Mizuno, M. Semi-transparent PV: Thermal performance, power generation, daylight modelling and energy saving potential in a residential application. Renew. Energy 2008, 33, 1024-1036. [CrossRef]

17. Peng, J.; Curcija, D.C.; Lu, L.; Selkowitz, S.E.; Yang, H.; Zhang, W. Numerical investigation of the energy saving potential of a semi-transparent photovoltaic double-skin facade in a cool-summer Mediterranean climate. Appl. Energy 2016, 165, 345-356. [CrossRef]

18. Bayoumi, M. Impacts of window opening grade on improving the energy efficiency of a façade in hot climates. Build. Environ. 2017, 119, 31-43. [CrossRef]

19. Elinwa, U.K.; Radmehr, M.; Ogbeba, J.E. Alternative Energy Solutions Using BIPV in Apartment Buildings of Developing Countries: A Case Study of North Cyprus. Sustainability 2017, 9, 1414. [CrossRef]

20. Song, A.; Lu, L.; Liu, Z.; Wong, M.S. A Study of Incentive Policies for Building-Integrated Photovoltaic Technology in Hong Kong. Sustainability 2016, 8, 769. [CrossRef]

21. Norton, B.; Eames, P.C.; Mallick, T.K.; Huang, M.J.; McCormack, S.J.; Mondol, J.D.; Yohanis, Y.G. Enhancing the performance of building integrated photovoltaics. Sol. Energy 2011, 85, 1629-1664. [CrossRef]

22. Agathokleous, R.A.; Kalogirou, S.A. Double skin facades (DSF) and building integrated photovoltaics (BIPV): A review of configurations and heat transfer characteristics. Renew. Energy 2016, 89, 743-756. [CrossRef]

23. Zhang, W.; Lu, L.; Peng, J. Evaluation of potential benefits of solar photovoltaic shadings in Hong Kong. Energy 2017. [CrossRef]

24. Ritzen, M.; Reijenga, T.; El Gammal, A.; Warneryd, M.; Sprenger, W.; Rose-Wilson, H.; Payet, J.; Morreau, V.; Boddaert, S. IEA-PVPS Task 15: Enabling Framework for BIPV Acceleration. (IEA-PVPS). In Proceedings of the 48th IEA PVPS Executive Commitee Meeting, Vienna, Austria, 16 November 2016.

25. Tabakovic, M.; Fechner, H.; Van Sark, W.; Louwen, A.; Georghiou, G.; Makrides, G.; Loucaidou, E.; Ioannidou, M.; Weiss, I.; Arancon, S.; et al. Status and outlook for building integrated photovoltaics (BIPV) in relation to educational needs in the BIPV sector. Energy Procedia 2017, 111, 993-999. [CrossRef]

26. Prieto, A.; Knaack, U.; Auer, T.; Klein, T. Solar façades-Main barriers for widespread façade integration of solar technologies. J. Façade Des. Eng. 2017, 5, 51-62. [CrossRef]

27. Goh, K.C.; Goh, H.H.; Yap, A.B.K.; Masrom, M.A.N.; Mohamed, S. Barriers and drivers of Malaysian BIPV application: Perspective of developers. Procedia Eng. 2017, 180, 1585-1595. [CrossRef]

28. Yang, R.J.; Zou, P.X. Building integrated photovoltaics (BIPV): Costs, benefits, risks, barriers and improvement strategy. Int. J. Constr. Manag. 2016, 16, 39-53. [CrossRef]

29. Karakaya, E.; Sriwannawit, P. Barriers to the adoption of photovoltaic systems: The state of the art. Renew. Sustain. Energy Rev. 2015, 49, 60-66. [CrossRef] 
30. Yang, R.J. Overcoming technical barriers and risks in the application of building integrated photovoltaics (BIPV): Hardware and software strategies. Autom. Constr. 2015, 51, 92-102. [CrossRef]

31. Azadian, F.; Radzi, M.A.M. A general approach toward building integrated photovoltaic systems and its implementation barriers: A review. Renew. Sustain. Energy Rev. 2013, 22, 527-538. [CrossRef]

32. Koinegg, J.; Brudermann, T.; Posch, A.; Mrotzek, M. “It Would Be a Shame if We Did Not Take Advantage of the Spirit of the Times". An Analysis of Prospects and Barriers of Building Integrated Photovoltaics. GAIA Ecol. Perspect. Sci. Soc. 2013, 22, 39-45. [CrossRef]

33. Probst, M.M.; Roecker, C. Criteria for architectural integration of active solar systems IEA Task 41, Subtask A. Energy Procedia 2012, 30, 1195-1204. [CrossRef]

34. Taleb, H.M.; Pitts, A.C. The potential to exploit use of building-integrated photovoltaics in countries of the Gulf Cooperation Council. Renew. Energy 2009, 34, 1092-1099. [CrossRef]

35. Tripathy, M.; Sadhu, P.K.; Panda, S.K. A critical review on building integrated photovoltaic products and their applications. Renew. Sustain. Energy Rev. 2016, 61, 451-465. [CrossRef]

36. Jelle, B.P. Building integrated photovoltaics: A concise description of the current state of the art and possible research pathways. Energies 2016, 9, 21. [CrossRef]

37. Heinstein, P.; Ballif, C.; Perret-Aebi, L.E. Building integrated photovoltaics (BIPV): Review, potentials, barriers and myths. Green 2013, 3, 125-156. [CrossRef]

38. Cerón, I.; Caamaño-Martín, E.; Neila, F.J. 'State-of-the-art' of building integrated photovoltaic products. Renew. Energy 2013, 58, 127-133. [CrossRef]

39. Bonomo, P.; Chatzipanagi, A.; Frontini, F. Overview and analysis of current BIPV products: New criteria for supporting the technological transfer in the building sector. VITRUVIO Int. J. Archit. Technol. Sustain. 2015, 67-85. [CrossRef]

40. Shukla, A.K.; Sudhakar, K.; Baredar, P. Recent advancement in BIPV product technologies: A review. Energy Build. 2017. [CrossRef]

41. Ibraheem, Y.; Farr, E.R.; Piroozfar, P.A. Embedding passive intelligence into building envelopes: A review of the state-of-the-art in integrated photovoltaic shading devices. Energy Procedia 2017, 111, 964-973. [CrossRef]

42. Shukla, A.K.; Sudhakar, K.; Baredar, P. A comprehensive review on design of building integrated photovoltaic system. Energy Build. 2016, 128, 99-110. [CrossRef]

43. Skandalos, N.; Karamanis, D. PV glazing technologies. Renew. Sustain. Energy Rev. 2015, 49, $306-322$. [CrossRef]

44. Jelle, B.P.; Breivik, C.; Røkenes, H.D. Building integrated photovoltaic products: A state-of-the-art review and future research opportunities. Sol. Energy Mater. Sol. Cells 2012, 100, 69-96. [CrossRef]

45. Jelle, B.P.; Breivik, C. The path to the building integrated photovoltaics of tomorrow. Energy Procedia 2012, 20, 78-87. [CrossRef]

46. Hammond, G.P.; Harajli, H.A.; Jones, C.I.; Winnett, A.B. Whole systems appraisal of a UK Building Integrated Photovoltaic (BIPV) system: Energy, environmental, and economic evaluations. Energy Policy 2012, 40, 219-230. [CrossRef]

47. Scognamiglio, A.; Røstvik, H.N. Photovoltaics and zero energy buildings: A new opportunity and challenge for design. Prog. Photovolt. Res. Appl. 2013, 21, 1319-1336. [CrossRef]

48. Scognamiglio, A.; Farkas, K.; Frontini, F.; Maturi, L. Architectural quality and photovoltaic products. In Proceedings of the 27th European Photovoltaic Solar Energy Conference and Exhibition (EU PVSEC), Frankfurt, Germany, 24-28 September 2012; pp. 24-28.

49. Stevenson, A. (Ed.) Oxford dictionary of English; Oxford University Press: New York, NY, USA, 2010.

50. Pine, B.J. Mass customizing products and services. Plan. Rev. 1993, 21, 6-55. [CrossRef]

51. Lien, S.Y. Artist Photovoltaic Modules. Energies 2016, 9, 551. [CrossRef]

52. Hardy, D.; Kerrouche, A.; Roaf, S.C.; Richards, B.S. Improving the Aesthetics of Photovoltaics through Use of Coloured Encapsulants. In Proceedings of the PLEA 2013-29th Conference, Sustainable Architecture for a Renewable Future, Munich, Germany, 10-12 September 2013.

53. Nagy, Z.; Svetozarevic, B.; Jayathissa, P.; Begle, M.; Hofer, J.; Lydon, G.; Willmann, A.; Schlueter, A. The adaptive solar facade: From concept to prototypes. Front. Archit. Res. 2016, 5, 143-156. [CrossRef]

54. Keller, A.F. Recharging the Facade: Designing and Constructing Novel BIPV Assemblies. Ph.D. Thesis, Massachusetts Institute of Technology, Cambridge, MA, USA, 2013. 
55. Hasan, A.; McCormack, S.J.; Huang, M.J.; Norton, B. Energy and cost saving of a photovoltaic-phase change materials (PV-PCM) system through temperature regulation and performance enhancement of photovoltaics. Energies 2014, 7, 1318-1331. [CrossRef]

56. Hasan, A.; McCormack, S.J.; Huang, M.J.; Sarwar, J.; Norton, B. Increased photovoltaic performance through temperature regulation by phase change materials: Materials comparison in different climates. Sol. Energy 2015, 115, 264-276. [CrossRef]

57. Hasan, A.; Sarwar, J.; Alnoman, H.; Abdelbaqi, S. Yearly energy performance of a photovoltaic-phase change material (PV-PCM) system in hot climate. Sol. Energy 2017, 146, 417-429. [CrossRef]

58. Baum, R. Architectural integration of light-transmissive photovoltaic (LTPV). In Proceedings of the 26th European Photovoltaic Solar Energy Conference and Exhibition (EU PVSEC), Hamburg, Germany, 5-9 September 2011; pp. 5-9.

59. Munari Probst, M.C.; Roecker, C.; Frontini, F.; Scognamiglio, A.; Farkas, K.; Maturi, L.; Zanetti, I. Solar Energy Systems in Architecture-integration criteria and guidelines. In International Energy Agency Solar Heating and Cooling Programme; Probst, M., Cristina, M., Roecker, C., Eds.; International Energy Agency: Paris, France, 2013.

60. Farkas, K.; Frontini, F.; Maturi, L.; Munari Probst, M.C.; Roecker, C.; Scognamiglio, A. Designing Photovoltaic Systems for Architectural Integration; Farkas, K., Ed.; International Energy Agency: Paris, France, 2013.

61. Montoro, D.F.; Vanbuggenhout, P.; Ciesielska, J. Building Integrated Photovoltaics: An overview of the existing products and their fields of application. In Report Prepared in the Framework of the European Funded Project; SUNRISE: Saskatoon, Canada, 2011.

62. Thomas, R. (Ed.) Photovoltaics and Architecture; Taylor \& Francis: Didcot, UK, 2003.

63. Clua Longas, A.; Lufkin, S.; Rey, E. Towards Advanced Active Façades: Analysis of façade requirements and development of an innovative construction system. In Proceedings of the PLEA 2017, Edinburgh, UK, 3-5 July 2017; Volume 1, pp. 192-199.

64. Luo, Y.; Zhang, L.; Wang, X.; Xie, L.; Liu, Z.; Wu, J.; Zhang, Y.; He, X. A comparative study on thermal performance evaluation of a new double skin façade system integrated with photovoltaic blinds. Appl. Energy 2017, 199, 281-293. [CrossRef]

65. Tabriz, S.N.; Fard, F.; Partovi, N. Review of architectural day lighting analysis of photovoltaic panels of BIPV with zero energy emission approach. Res. J. Appl. Sci. 2016, 11, 735-741.

66. Pagliaro, M.; Ciriminna, R.; Palmisano, G. BIPV: Merging the photovoltaic with the construction industry. Prog. Photovolt. Res. Appl. 2010, 18, 61-72. [CrossRef]

67. Oliver, M.; Jackson, T. Energy and economic evaluation of building-integrated photovoltaics. Energy 2001, 26, 431-439. [CrossRef]

68. Bakos, G.C.; Soursos, M.; Tsagas, N.F. Technoeconomic assessment of a building-integrated PV system for electrical energy saving in residential sector. Energy Build. 2003, 35, 757-762. [CrossRef]

69. Sharples, S.; Radhi, H. Assessing the technical and economic performance of building integrated photovoltaics and their value to the GCC society. Renew. Energy 2013, 55, 150-159. [CrossRef]

70. Byrnes, L.; Brown, C.; Foster, J.; Wagner, L.D. Australian renewable energy policy: Barriers and challenges. Renew. Energy 2013, 60, 711-721. [CrossRef]

71. Morris, S. Improving Energy Efficient, Sustainable Building Design and Construction in Australia-Learning from Europe; ISS Institute: Carlton, Australia, 2013.

72. Abdullah, A.S.; Abdullah, M.P.; Hassan, M.Y.; Hussin, F. Renewable energy cost-benefit analysis under Malaysian feed-in-tariff. In Proceedings of the 2012 IEEE Student Conference on Research and Development (SCOReD), Pulau Pinang, Malaysia, 5-6 December 2012; pp. 160-165.

73. Sintov, N.D.; Schultz, P. Adjustable Green Defaults Can Help Make Smart Homes More Sustainable. Sustainability 2017, 9, 622. [CrossRef]

74. Martyn, A.S. Some problems in managing complex development projects. Long Range Plann. 1975, 8, 13-26. [CrossRef]

75. Attoye, D.E.; Tabet Aoul, K.A.; Hassan, A. Potentials and Benefits of Building Integrated Photovoltaics. In Proceedings of the United Arab Emirates Graduate Student Conference (UAEGSRC), Al Ain, UAE, 27-28 April 2016.

76. Jahanara, A. Strategy towards Solar Architecture by Photovoltaic for Building Integration. Ph.D. Thesis, Eastern Mediterranean University (EMU), Famagusta, Turkey, 2013. 
77. Wu, Y.; Krishnan, P.; Liya, E.Y.; Zhang, M.H. Using lightweight cement composite and photocatalytic coating to reduce cooling energy consumption of buildings. Constr. Build. Mater. 2017, 145, 555-564. [CrossRef]

78. Biyik, E.; Araz, M.; Hepbasli, A.; Shahrestani, M.; Yao, R.; Shao, L.; Essah, E.; Oliveira, A.C.; del Caño, T.; Rico, E.; et al. A key review of building integrated photovoltaic (BIPV) systems. Eng. Sci. Technol. Int. J. 2017. [CrossRef]

79. Tak, S.; Woo, S.; Park, J.; Park, S. Effect of the Changeable Organic Semi-Transparent Solar Cell Window on Building Energy Efficiency and User Comfort. Sustainability 2017, 9, 950. [CrossRef]

80. Peharz, G.; Berger, K.; Kubicek, B.; Aichinger, M.; Grobbauer, M.; Gratzer, J.; Nemitz, W.; Großschädl, B.; Auer, C.; Prietl, C.; et al. Application of plasmonic coloring for making building integrated PV modules comprising of green solar cells. Renew. Energy 2017, 109, 542-550. [CrossRef]

81. Van Berkel, T.; Minderhoud, T.; Piber, A.; Gijzen, G. Design Innovation from PV-Module to Building Envelope: Architectural Layering and Non Apparent Repetition. In Proceedings of the 29th European Photovoltaic Solar Energy Conference and Exhibition, Amsterdam, The Netherlands, 22-26 September 2014; pp. 366-372.

82. Lim, J.W.; Kim, G.; Shin, M.; Yun, S.J. Colored a-Si: H transparent solar cells employing ultrathin transparent multi-layered electrodes. Sol. Energy Mater. Sol. Cells 2017, 163, 164-169. [CrossRef]

83. Wang, M.; Peng, J.; Li, N.; Yang, H.; Wang, C.; Li, X.; Lu, T. Comparison of energy performance between PV double skin facades and PV insulating glass units. Appl. Energy 2017, 194, 148-160. [CrossRef]

84. Peng, J.; Lu, L.; Yang, H.; Sing, A.; Ma, T. 182: Investigation on the overall energy performance of an a-si based photovoltaic double-skin facade in Hong Kong. In Proceedings of the Sustainable Energy for a Resilient Future: The 14th International Conference on Sustainable Energy Technologies, Nottingham, UK, 25-27 August 2015; Rodrigues, L., Ed.; University of Nottingham: Nottingham, UK, 2015; Volume 1, pp. 263-271.

85. Chatzipanagi, A.; Frontini, F.; Virtuani, A. BIPV-temp: A demonstrative Building Integrated Photovoltaic installation. Appl. Energy 2016, 173, 1-2. [CrossRef]

86. Wang, M.; Peng, J.; Li, N.; Lu, L.; Ma, T.; Yang, H. Assessment of energy performance of semi-transparent PV insulating glass units using a validated simulation model. Energy 2016, 112, 538-548. [CrossRef]

87. Do, S.L.; Shin, M.; Baltazar, J.C.; Kim, J. Energy benefits from semi-transparent BIPV window and daylight-dimming systems for IECC code-compliance residential buildings in hot and humid climates. Sol. Energy 2017, 155, 291-303. [CrossRef]

88. Hachem, C.; Elsayed, M. Patterns of façade system design for enhanced energy performance of multistory buildings. Energy Build. 2016, 130, 366-377. [CrossRef]

89. Huang, Y.C.; Lee, S.K.; Chan, C.C.; Wang, S.J. Full-scale evaluation of fire-resistant building integrated photovoltaic systems with different installation positions of junction boxes. Indoor Built Environ. 2017. [CrossRef]

90. Elarga, H.; Zarrella, A.; De Carli, M. Dynamic energy evaluation and glazing layers optimization of facade building with innovative integration of PV modules. Energy Build. 2016, 111, 468-478. [CrossRef]

91. Curpek, J.; Hraska, J. Simulation Study on Thermal Performance of a Ventilated PV Façade Coupled with PCM. In Applied Mechanics and Materials; Trans Tech Publications: Zürich, Switzerland, 2017; Volume 861, pp. 167-174.

92. Gaillard, L.; Giroux-Julien, S.; Ménézo, C.; Pabiou, H. Experimental evaluation of a naturally ventilated PV double-skin building envelope in real operating conditions. Sol. Energy 2014, 103, 223-441. [CrossRef]

93. Bahr, W. A comprehensive assessment methodology of the building integrated photovoltaic blind system. Energy Build. 2014, 82, 703-708. [CrossRef]

94. Peng, J.; Lu, L.; Yang, H.; Han, J. Investigation on the annual thermal performance of a photovoltaic wall mounted on a multi-layer façade. Appl. Energy 2013, 112, 646-656. [CrossRef]

95. Buscemi, A.; Calabrò, C.; Corrao, R.; Di Maggio, M.S.; Morini, M.; Pastore, L. Optical Performance Evaluation of DSSC-integrated Glassblocks for Active Building Façades. Int. J. Mod. Eng. Res. 2015, 5, 1-6.

96. Valckenborg, R.M.E.; van der Wall, W.; Folkerts, W.; Hensen, J.L.M.; de Vries, A. Zigzag Structure in Façade Optimizes PV Yield While Aesthetics are Preserved. In Proceedings of the 32nd European Photovoltaic Solar Energy Conference and Exhibition, Munich, Germany, 20-24 June 2016; European Commission: Brussels, Belgium; pp. 647-650.

97. Wall, M.; Probst, M.C.M.; Roecker, C.; Dubois, M.C.; Horvat, M.; Jørgensen, O.B.; Kappel, K. Achieving solar energy in architecture-IEA SHC Task 41. Energy Procedia 2012, 30, 1250-1260. [CrossRef] 
98. Benemann, J.; Chehab, O.; Schaar-Gabriel, E. Building-integrated PV modules. Sol. Energy Mater. Sol. Cells 2001, 67, 345-354. [CrossRef]

99. Zanetti, I.; Bonomo, P.; Frontini, P.; Saretta, E.; Verberne, G.; Van Den Donker, M.; Sinapis, K.; Folkerts, W. Building Integrated Photovoltaics. Report 2017; SUPSI-University of Applied Sciences and Arts of Southern Switzerland, Ed.; SUPSI: Lugano, Switzerland, 2017.

100. Cannavale, A.; Hörantner, M.; Eperon, G.E.; Snaith, H.J.; Fiorito, F.; Ayr, U.; Martellotta, F. Building integration of semitransparent perovskite-based solar cells: Energy performance and visual comfort assessment. Appl. Energy 2017, 194, 94-107. [CrossRef]

101. Pandey, A.K.; Tyagi, V.V.; Jeyraj, A.; Selvaraj, L.; Rahim, N.A.; Tyagi, S.K. Recent advances in solar photovoltaic systems for emerging trends and advanced applications. Renew. Sustain. Energy Rev. 2016, 53, 859-884. [CrossRef]

102. Chemisana, D. Building integrated concentrating photovoltaics: A review. Renew. Sustain. Energy Rev. 2011, 15, 603-611. [CrossRef]

103. Hyder, F.; Sudhakar, K.; Mamat, R. Solar PV tree design: A review. Renew. Sustain. Energ. Rev. 2018, 82, 1079-1096. [CrossRef]

(C) 2017 by the authors. Licensee MDPI, Basel, Switzerland. This article is an open access article distributed under the terms and conditions of the Creative Commons Attribution (CC BY) license (http:/ / creativecommons.org/licenses/by/4.0/). 